\title{
Clinical Data on Immunotherapy in Breast Cancer
}

\author{
Julia Caroline Radosa ${ }^{a} \quad$ Lisa Stotz $^{a} \quad$ Carolin Müller $^{a} \quad$ Askin Canguel Kaya ${ }^{a}$ \\ Erich-Franz Solomayer ${ }^{a}$ Marc Philipp Radosab

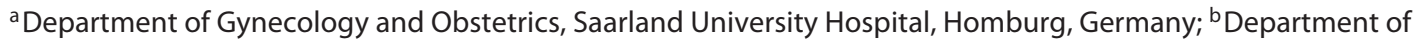 \\ Gynecology and Obstetrics, Klinikum Bremen-Nord, Bremen, Germany
}

\section{Keywords}

Breast cancer · Immunotherapy · Immune checkpoint inhibition · CAR T-cell therapy · Tumor vaccination

\begin{abstract}
Background: Breast cancer has traditionally been considered to have a low immunogenic potential compared to other tumor entities. Summary: The most extensively studied immunotherapeutic agents for breast cancer to date are immune checkpoint inhibitors, with the results of the IMpassion130 trial leading to the approval of atezolizumab plus nab-paclitaxel for first-line treatment of programmed cell death ligand 1-positive, metastatic, triple-negative breast cancer, and studies in earlier stages have yielded promising results. Other immunotherapeutic options being assessed in phases 2 and 3 trials include vaccine-based therapies and treatment with anti-human epidermal growth factor receptor 2 ( $\mathrm{H}$-directed immune-linked antibodies) and substances evaluated in early clinical trials as cellular therapies (adoptive cell therapy and chimeric antigen receptor T cells). Key Messages: Immunotherapy is an emerging modality for the treatment of breast cancer, as evidenced by the plethora of preclinical and clinical concepts and ongoing trials. Early studies established the role of immunotherapeutic agents in the metastatic setting. Ongoing studies will expand our knowledge about the timing of administration, best partners for combination therapy, and predictive biomarkers to guide immunotherapy for breast cancer. @ 2020 The Author(s)
\end{abstract}

Published by S. Karger AG, Basel

\section{Introduction}

The immune system plays a crucial role in cancer development and inherits tumor-stimulating and tumorimpeding capacities. Immunologically, tumor progression can be suppressed by the prevention or inhibition of tumor growth or promoted by the facilitation of cellular transformation or influencing of the tumor microenvironment to create favorable conditions [1,2]. These unique, host-protecting and cancer-promoting features of the immune system are encompassed by the concept of "immunoediting." This dynamic process has 3 phases (elimination, equilibrium, and escape), which describe how tumor cells escape from immune surveillance or are eradicated through the activation of innate and adaptive immune mechanisms [3]. Breast cancer has traditionally been considered to be a disease with a low immunogenic potential (a so-called "cold" tumor) compared to other tumor entities, such as melanoma and lung cancer, given its lower mutational burden, the smaller number of tumor-infiltrating lymphocytes (TIL), and the lesser programmed cell death protein/ligand (PD-1/L1) expression $[4,5]$. However, with a better understanding of breast cancer biology and tumor and immunological profiling, this view began to change, leading to the development of new concepts of potential mechanisms of immune evasion and aspects of the tumor microenvironment. Although the breast cancer immune landscape is dynamic and heterogeneous, with considerable variation among

Julia Caroline Radosa

Department of Gynecology and Obstetrics, Saarland University Hospital Kirrbergerstrasse 100

DE-66421 Homburg (Germany)

Julia.radosa@uks.eu 
tumor stages and between subtypes (triple-negative vs. other subtypes) and disease settings (early vs. metastatic), the clinical evidence of responsiveness to various immunotherapies is accumulating [6]. An emerging body of preclinical and clinical data and ongoing studies addresses immunotherapy in neoadjuvant, adjuvant, and metastatic disease settings and for different subtypes of breast cancer and immunotherapy combinations. This review summarizes key clinical trials, recent findings, and emerging therapeutic concepts in the field of immunotherapy for breast cancer.

\section{Immunotherapy in Breast Cancer}

\section{Immune Checkpoint Inhibition}

Important targets in the cancer-immunity cycle are immune checkpoints; interactions with cell surface proteins can be blocked by immune checkpoint inhibitors (ICI). The most promising and most studied ICI in breast cancer to date are anti-PD-1/L-1 antibodies [7]. The $\mathrm{PD}-1 / \mathrm{PD}-\mathrm{L} 1$ pathway represents an adaptive immune resistance mechanism of tumor cells. Binding between PD1 , which is expressed on T cells, and PD-L1, which is expressed on tumor cells, inhibits the antitumoral T-celladapted immune response. Blockage of this pathway via checkpoint inhibitors "releases the brakes" of the immune system in the battle against cancer cells and can reactivate immune surveillance and antitumoral immune activity $[1,8,9]$. Immunotherapy in general and ICI specifically have shown the most promising results to date for triple-negative breast cancer, which is characterized by a greater PD-L1 expression relative to other breast cancer subtypes $[5,10]$.

\section{Metastatic Breast Cancer}

The use of several ICI as monotherapy for metastatic triple-negative breast cancer has been studied, with moderate but durable response rates and tolerable safety profiles observed [11-13]. These effects seem to be restricted mostly to first-line treatment of metastatic disease and to PD-L1-positive tumors. For example, the phase $2 \mathrm{KEY}$ NOTE-086 study assessed pembrolizumab monotherapy ( $200 \mathrm{mg}$ i.v. every 3 weeks) with regard to PD-L1 status and line of therapy in 170 patients with metastatic triplenegative breast cancer receiving pretreatment (cohort A, $62 \% \mathrm{PD}-\mathrm{L} 1$ positive) and 84 such patients receiving firstline treatment (cohort B, 100\% PD-L1 positive) [14]. Objective response rates were $5.3 \%$ in cohort $A(5.7 \%$ in PD-L1-positive patients) and $21.4 \%$ in cohort $\mathrm{B}$, with a median response duration of 10.4 months in cohort $\mathrm{B}$ (not achieved in cohort A). The median progression-free survival (PFS) was 2 months (95\% CI 1.9-2.0 months) in cohort A and 2.1 months (95\% CI 2.0-2.2 months) in co- hort B, and the median overall survival (OS) was 9.0 (95\% CI 7.6-11.2) and 18.0 (95\% CI 9.0-23.0) months, respectively [14]. Similar results were obtained for atezolizumab monotherapy in a phase 1 study conducted in patients with metastatic or locally advanced triple-negative breast cancer; objective response rates were $24 \%$ for first-line treatment and $6 \%$ for later lines, and 12\% for PD-L1-positive tumors and $0 \%$ for PD-L1-negative tumors [11]. Studies comparing ICI monotherapy with chemotherapy, such as the KEYNOTE-012 study, in which second-/ third-line pembrolizumab treatment was compared with single-agent chemotherapy (capecitabine, eribulin, gemcitabine, or vinorelbine) of the physicians' choice for patients with metastatic triple-negative breast cancer, have revealed no significant difference in OS between groups [15]. These studies have shown that the effects of PD-L1 inhibitors for the treatment of metastatic triple-negative breast cancer are strongest for early treatment lines and PD-L1-overexpressing cancers. Given the immunomodulatory effects of chemotherapy, which are based partly on the induction of tumor-associated antigen (TAA) release, the next step was to examine the use of ICI combined with chemotherapy [16]. IMpassion130, a phase 3 study, evaluated the use of nab-paclitaxel $\left(100 \mathrm{mg} / \mathrm{m}^{2}\right.$ i.v. on days 1,8 , and 15) plus atezolizumab (840 $\mathrm{mg}$ i.v. on days 1 and 15 of every 28-day cycle) or placebo for the treatment of first-line metastatic or locally advanced triple-negative breast cancer [17]. The enrolled patients had tumor relapse $\geq 12$ months after completion of (neo)adjuvant chemotherapy. PFS was significantly longer in the atezolizumab-plus-chemotherapy arm of the intentionto-treat (ITT) population (7.2 vs. 5.5 months; $p=0.0025$ ) and in the subgroup with PD-L1-positive tumors (7.5 vs. 5.0 months). OS did not differ significantly in the ITT population (21.3 vs. 17.6 months), but it reflected a "clinically meaningful" benefit in patients with PD-L1-positive tumors treated with combination therapy (25.0 vs. 18.0 months; HR $=0.71$; 95\% CI 0.54-0.94) [17]. However, formal statistical testing of these data could not be performed because OS was not predefined as a primary outcome in case of a nonsignificant difference in the ITT population. Grade 3 and 4 adverse events occurred in $48.7 \%$ of patients receiving atezolizumab and in $42.2 \%$ of those receiving placebo. The most frequent adverse events were neutropenia, peripheral neuropathy, decreased neutrophil count, and fatigue. Two treatment-related deaths (caused by autoimmune hepatitis and septic shock, respectively) occurred in the experimental arm and 1 death (caused by hepatic failure) occurred in the placebo arm. Adverse events leading to the discontinuation of therapy occurred in $15.9 \%$ of patients receiving atezolizumab and in $8.2 \%$ of those receiving a placebo [17]. The IMpassion 130 study led to US Food and Drug Administration (FDA) approval of atezolizumab for patients with unre- 
Table 1. Immune checkpoint blockade trials for metastatic breast cancer in the recruitment phase

\begin{tabular}{|c|c|c|}
\hline Agent & Trial / Phase & Setting \\
\hline \multirow[t]{28}{*}{ Pembrolizumab } & Focused Ultrasound and Pembrolizumab in Metastatic Breast Cancer / Phase 1 & Metastatic \\
\hline & $\begin{array}{l}\text { Study of Pembrolizumab Plus Fulvestrant in Hormone Receptor Positive, HER-2-Negative Advanced/Metastatic } \\
\text { Breast Cancer Patients / Phase } 2\end{array}$ & Metastatic \\
\hline & PVX-410 Vaccine plus Pembrolizumab in HLA-A2+ Metastatic Triple-Negative Breast Cancer / Phase 2 & Metastatic \\
\hline & $\begin{array}{l}\text { Establishing the Recommended Biological Dose for AE } 37 \text { Peptide Vaccine in Combination with Pembrolizumab that } \\
\text { Will Enhance the Tumor-Specific Immune Response and Demonstrate Efficacy in Patients with Advanced Triple- } \\
\text { Negative Breast Cancer / Phase } 2\end{array}$ & Metastatic \\
\hline & $\begin{array}{l}\text { Phase 1b Study of Pegylated Liposomal Doxorubicin and Pembrolizumab in Endocrine-Resistant Breast Cancer / } \\
\text { Phase } 1\end{array}$ & Metastatic \\
\hline & A Study to Evaluate Concurrent VRP-HER2 Vaccination and Pembrolizumab for Patients with Breast Cancer / Phase 2 & Metastatic \\
\hline & $\begin{array}{l}\text { Pembrolizumab and Exemestane/Leuprolide in Premenopausal HR+/HER2- Locally Advanced or Metastatic Breast } \\
\text { Cancer / Phases } 1 \text { and } 2\end{array}$ & Metastatic \\
\hline & Her2-BATS and Pembrolizumab in Metastatic Breast Cancer/ Phases 1 and 2 & Metastatic \\
\hline & Phase II Study of Pembrolizumab and Nab-Paclitaxel in HER-2-Negative Metastatic Breast Cancer / Phase 2 & Metastatic \\
\hline & A Study Of Pembrolizumab in Combination with Trastuzumab-DM1 / Phase 1 & Metastatic \\
\hline & $\begin{array}{l}\text { Safety and Efficacy of SGN-LIV1A plus Pembrolizumab for Patients with Locally Advanced or Metastatic Triple- } \\
\text { Negative Breast Cancer / Phases } 1 \text { and } 2\end{array}$ & Metastatic \\
\hline & Pilot Study of Paclitaxel plus Pembrolizumab in Metastatic HER2-Negative Breast Cancer / Phase 2 & Metastatic \\
\hline & $\begin{array}{l}\text { Study of Olaparib plus Pembrolizumab versus Chemotherapy plus Pembrolizumab after Induction with First-Line } \\
\text { Chemotherapy plus Pembrolizumab in Triple-Negative Breast Cancer (TNBC) (MK-7339-009/KEYLYNK-009) / } \\
\text { Phases } 2 \text { and } 3\end{array}$ & Metastatic \\
\hline & $\begin{array}{l}\text { Intratumoral Tavo and Pembro in Patients with Inoperable Locally Advanced or Metastatic TNBC (KEYNOTE-890) / } \\
\text { Phase } 2\end{array}$ & Metastatic \\
\hline & $\begin{array}{l}\text { A Study of Pembrolizumab with Carboplatin and Gemcitabine in Patients with Metastatic Triple-Negative Breast } \\
\text { Cancer / Phase } 2\end{array}$ & Metastatic \\
\hline & $\begin{array}{l}\text { Pembrolizumab, Letrozole, and Palbociclib in Treating Postmenopausal Patients with Newly Diagnosed Metastatic } \\
\text { Stage IV Estrogen Receptor-Positive Breast Cancer / Phase } 2\end{array}$ & Metastatic \\
\hline & $\begin{array}{l}\text { Pembrolizumab and Ruxolitinib Phosphate in Treating Patients with Metastatic Stage IV Triple-Negative Breast } \\
\text { Cancer / Phase } 1\end{array}$ & Metastatic \\
\hline & $\begin{array}{l}\text { Chemokine Modulation Therapy and Pembrolizumab in Treating Participants With Metastatic Triple-Negative } \\
\text { Breast Cancer / Phase } 1\end{array}$ & Metastatic \\
\hline & SBRT and Oncolytic Virus Therapy before Pembrolizumab for Metastatic TNBC and NSCLC / Phase 2 & Metastatic \\
\hline & $\begin{array}{l}\text { Pembrolizumab and Carboplatin in Treating Patients with Circulating Tumor Cells Positive Metastatic Breast } \\
\text { Cancer / Phase } 2\end{array}$ & Metastatic \\
\hline & $\begin{array}{l}\text { A Study of EDP1503 in Patients with Colorectal Cancer, Breast Cancer, and Checkpoint Inhibitor Relapsed Tumors / } \\
\text { Phases } 1 \text { and } 2\end{array}$ & Metastatic \\
\hline & Vaccination with Flt3L, Radiation, and Poly-ICLC / Phases 1 and 2 & Metastatic \\
\hline & $\begin{array}{l}\text { DS8201a and Pembrolizumab in Participants with Locally Advanced/Metastatic Breast or Non-Small Cell Lung } \\
\text { Cancer / Phase } 1\end{array}$ & Metastatic \\
\hline & $\begin{array}{l}\text { Tesetaxel plus } 3 \text { Different PD-(L)1 Inhibitors in Patients with Metastatic TNBC and Tesetaxel Monotherapy in } \\
\text { Patients with HER2 Negative MBC / Phase } 2\end{array}$ & Metastatic \\
\hline & Phase 1a/1b Study of TPST-1495 Alone and with Pembrolizumab in Subjects with Solid Tumors / Phase 1 & Metastatic \\
\hline & $\begin{array}{l}\text { CPI-006 Alone and in Combination with Ciforadenant and with Pembrolizumab for Patients with Advanced } \\
\text { Cancers / Phase } 1\end{array}$ & Metastatic \\
\hline & $\begin{array}{l}\text { Pembrolizumab in Treating Participants with Metastatic, Recurrent or Locally Advanced Cancer and Genomic } \\
\text { Instability / Phase } 2\end{array}$ & Metastatic \\
\hline & Immunotherapy Using Tumor Infiltrating Lymphocytes for Patients with Metastatic Cancer / Phase 2 & Metastatic \\
\hline
\end{tabular}


Table 1 (continued)

\begin{tabular}{|c|c|c|}
\hline Agent & Trial / Phase & Setting \\
\hline & $\begin{array}{l}\text { A Study of XmAb®22841 Monotherapy and in Combination w/ Pembrolizumab in Subjects w/ Selected Advanced } \\
\text { Solid Tumors / Phase } 1\end{array}$ & Metastatic \\
\hline & $\begin{array}{l}\text { Study of SO-C101 and SO-C101in Combination with Pembro in Adult Patients with Advanced/Metastatic Solid } \\
\text { Tumors / Phase } 1\end{array}$ & Metastatic \\
\hline & A Study of ZN-c3 in Participants with Solid Tumors / Phases 1 and 2 & Metastatic \\
\hline & $\begin{array}{l}\text { A Personalized Medicine Study for Patients with Advanced Cancer of the Breast, Prostate, Pancreas or Those with } \\
\text { Refractory Acute Myelogenous Leukemia / Phase } 1\end{array}$ & Metastatic \\
\hline & A First-in-Human Study Using BDC-1001 in Advanced and HER2-Expressing Solid Tumors / Phase 1 & Metastatic \\
\hline & Pembrolizumab with Intratumoral Injection of Clostridium Novyi-NT / Phase 1 & Metastatic \\
\hline & $\begin{array}{l}\text { Malignant Pleural Disease Treated With Autologous T Cells Genetically Engineered to Target the Cancer-Cell Surface } \\
\text { Antigen Mesothelin / Phases } 1 \text { and } 2\end{array}$ & Metastatic \\
\hline & $\begin{array}{l}\text { GB1275 Monotherapy and in Combination with an Anti-PD1 Antibody in Patients with Specified Advanced Solid } \\
\text { Tumors or in Combination with Standard of Care in Patients with Metastatic Pancreatic Adenocarcinoma / Phases } 1 \\
\text { and } 2\end{array}$ & Metastatic \\
\hline & $\begin{array}{l}\text { Study of ONCR-177 Alone and in Combination with PD-1 Blockade in Adult Subjects with Advanced and/or } \\
\text { Refractory Cutaneous, Subcutaneous or Metastatic Nodal Solid Tumors / Phase } 1\end{array}$ & Metastatic \\
\hline & $\begin{array}{l}\text { Trans-Artery/Intra-Tumor Infusion of Checkpoint Inhibitors for Immunotherapy of Advanced Solid Tumors / } \\
\text { Phases } 2 \text { and } 3\end{array}$ & Metastatic \\
\hline & $\begin{array}{l}\text { Administration of Autologous T-Cells Genetically Engineered to Express T-Cell Receptors Reactive against Mutated } \\
\text { Neoantigens in People with Metastatic Cancer / Phase } 2\end{array}$ & Metastatic \\
\hline & A Study of CDX-1140 as Monotherapy or in Combination in Patients with Advanced Malignancies / Phase 1 & Metastatic \\
\hline & $\begin{array}{l}\text { FT500 as Monotherapy and in Combination with Immune Checkpoint Inhibitors in Subjects with Advanced Solid } \\
\text { Tumors / Phase } 1\end{array}$ & Metastatic \\
\hline & $\begin{array}{l}\text { Dose Escalation and Expansion Study of FLX } 475 \text { Monotherapy and in Combination with Pembrolizumab / Phases } 1 \\
\text { and } 2\end{array}$ & Metastatic \\
\hline & A Phase 1/2 Safety Study of Intratumorally Dosed INT230-6 / Phases 1 and 2 & Metastatic \\
\hline & Study of DF1001 in Patients with Advanced Solid Tumors / Phases 1 and 2 & Metastatic \\
\hline & $\begin{array}{l}\text { Open-Label, Dose-Escalation Study of Pemigatinib in Subjects with Advanced Malignancies - (FIGHT-101) / Phases } \\
1 \text { and } 2\end{array}$ & Metastatic \\
\hline & Dose Escalation Study of GSK3326595 in Subjects with Solid Tumors and Non-Hodgkin’s Lymphoma / Phase 1 & Metastatic \\
\hline & Focused Ultrasound Ablation and PD-1 Antibody Blockade in Advanced Solid Tumors / Phase 1 & Metastatic \\
\hline \multirow[t]{11}{*}{ Nivolumab } & Carboplatin +/- Nivolumab in Metastatic Triple-Negative Breast Cancer / Phase 2 & Metastatic \\
\hline & NIMBUS: Nivolumab plus Ipilimumab in Metastatic Hypermutated HER2-Negative Breast Cancer / Phase 2 & Metastatic \\
\hline & Nivolumab and Eribulin in HER2-Negative Metastatic Breast Cancer / Phases 1 and 2 & Metastatic \\
\hline & Pre-Operative Trial for Breast Cancer with Nivolumab in Combination with Novel IO / Phase 2 & Metastatic \\
\hline & Stereotactic Radiation and Nivolumab in the Management of Metastatic Breast Cancer Brain Metastases / Phase 1 & Metastatic \\
\hline & $\begin{array}{l}\text { Phase IIb Study Evaluating Immunogenic Chemotherapy Combined with Ipilimumab and Nivolumab in Breast } \\
\text { Cancer / Phase } 2\end{array}$ & Metastatic \\
\hline & $\begin{array}{l}\text { Nivolumab, Ipilimumab, and Bicalutamide in Human Epidermal Growth Factor (HER) 2-Negative Breast Cancer } \\
\text { Patients / Phase } 2\end{array}$ & Metastatic \\
\hline & $\begin{array}{l}\text { Immune Induction Strategies to Improve Response to Immune Checkpoint Blockade in Triple-Negative Breast } \\
\text { Cancer (TNBC) Patients / Phase } 2\end{array}$ & Metastatic \\
\hline & Trastuzumab Deruxtecan with Nivolumab in Advanced Breast and Urothelial Cancer / Phase I & Metastatic \\
\hline & $\begin{array}{l}\text { Sequentional Immuno Apheresis Plasma Volume Escalation Cohort Study of Removal of Soluble Tumor Necrosis } \\
\text { Factor Receptors } 1 \text { and } 2 \text { (sTNFR1/2) with or without Nivolumab in Patients with Inoperable or Metastatic Solid } \\
\text { Tumors }\end{array}$ & Metastatic \\
\hline & $\begin{array}{l}\text { Tesetaxel plus } 3 \text { Different PD-(L)1 Inhibitors in Patients with Metastatic TNBC and Tesetaxel Monotherapy in } \\
\text { Patients with HER2-Negative MBC / Phase } 2\end{array}$ & Metastatic \\
\hline
\end{tabular}


Table 1 (continued)

\begin{tabular}{|c|c|c|}
\hline \multirow[t]{9}{*}{ Agent } & Trial / Phase & Setting \\
\hline & Study BT5528-100 in Patients with Advanced Solid Tumors Associated with EphA2 Expression / Phases 1 and 2 & Metastatic \\
\hline & $\begin{array}{l}\text { A Study of NKTR-262 in Combination with NKTR-214 and with NKTR-214 plus Nivolumab in Patients with Locally } \\
\text { Advanced or Metastatic Solid Tumor Malignancies / Phases } 1 \text { and } 2\end{array}$ & Metastatic \\
\hline & $\begin{array}{l}\text { A Dose-Escalation Study to Evaluate the Safety, Tolerability, Pharmacokinetics, and Pharmacodynamics of IPI-549 / } \\
\text { Phase } 1\end{array}$ & Metastatic \\
\hline & $\begin{array}{l}\text { A Dose Escalation and Cohort Expansion Study of NKTR-214 in Combination with Nivolumab and Other Anti- } \\
\text { Cancer Therapies in Patients with Select Advanced Solid Tumors (PIVOT-02) / Phases } 1 \text { and } 2\end{array}$ & Metastatic \\
\hline & $\begin{array}{l}\text { A Personalized Medicine Study for Patients with Advanced Cancer of the Breast, Prostate, Pancreas or Those with } \\
\text { Refractory Acute Myelogenous Leukemia / Phase } 1\end{array}$ & Metastatic \\
\hline & $\begin{array}{l}\text { A Study of Gene Edited Autologous Neoantigen Targeted TCR T Cells with or without Anti-PD-1 in Patients with } \\
\text { Solid Tumors / Phase } 1\end{array}$ & Metastatic \\
\hline & A Study of ASP1948, Targeting an Immune Modulatory Receptor, in Subjects with Advanced Solid Tumors / Phase 1 & Metastatic \\
\hline & $\begin{array}{l}\text { Phase 1/2 Study Exploring the Safety, Tolerability, and Efficacy of INCAGN01876 Combined with Immune Therapies } \\
\text { in Advanced or Metastatic Malignancies / Phases } 1 \text { and } 2\end{array}$ & Metastatic \\
\hline \multirow[t]{20}{*}{ Atezolizumab } & Atezolizumab + Stereotactic Radiation in Triple-Negative Breast Cancer and Brain Metastasis / Phase 2 & Metastatic \\
\hline & 89Zr-Atezolizumab PET Scan and Lobular Breast Cancer & Metastatic \\
\hline & Assessing Efficacy of Carboplatin and Atezolizumab in Metastatic Lobular Breast Cancer / Phase 2 & Metastatic \\
\hline & $\begin{array}{l}\text { A Study of Atezolizumab and Paclitaxel Versus Placebo and Paclitaxel in Participants with Previously Untreated } \\
\text { Locally Advanced or Metastatic Triple-Negative Breast Cancer (TNBC) / Phase } 3\end{array}$ & Metastatic \\
\hline & $\begin{array}{l}\text { A Study of Atezolizumab plus Nab-Paclitaxel or Paclitaxel in the Treatment of Unresectable Locally Advanced or } \\
\text { Metastatic Triple-Negative Breast Cancer / Phase } 3\end{array}$ & Metastatic \\
\hline & Stereotactic Radiation and Immunotherapy in Patients with Advanced Triple Negative Breast Cancer / Phase 2 & Metastatic \\
\hline & $\begin{array}{l}\text { Triple-B Study; Carboplatin-Cyclophosphamide versus Paclitaxel with or without Atezolizumab as First-Line } \\
\text { Treatment in Advanced Triple-Negative Breast Cancer / Phase } 2\end{array}$ & Metastatic \\
\hline & $\begin{array}{l}\text { Clinical Trial of Atezolizumab with Paclitaxel, Trastuzumab, and Pertuzumab in Patients with Metastatic HER-2- } \\
\text { Positive Breast Cancer / Phase } 2\end{array}$ & Metastatic \\
\hline & $\begin{array}{l}\text { A Study Of Ipatasertib in Combination with Atezolizumab and Paclitaxel as a Treatment for Participants with Locally } \\
\text { Advanced or Metastatic Triple-Negative Breast Cancer / Phase } 3\end{array}$ & Metastatic \\
\hline & $\begin{array}{l}\text { Atezolizumab Combined with Immunogenic Chemotherapy in Patients with Metastatic Triple-Negative Breast } \\
\text { Cancer / Phase } 2\end{array}$ & Metastatic \\
\hline & $\begin{array}{l}\text { A Study to Evaluate the Safety and Efficacy of Ipatasertib in Combination with Atezolizumab and Paclitaxel or Nab- } \\
\text { Paclitaxel in Participants with Locally Advanced or Metastatic Triple-Negative Breast Cancer / Phase } 1\end{array}$ & Metastatic \\
\hline & $\begin{array}{l}\text { A Study of the Efficacy and Safety of Atezolizumab plus Chemotherapy for Patients with Early Relapsing Recurrent } \\
\text { Triple-Negative Breast Cancer / Phase } 3\end{array}$ & Metastatic \\
\hline & Carboplatin with or without Atezolizumab in Treating Patients with Stage IV Triple-Negative Breast Cancer / Phase 2 & Metastatic \\
\hline & $\begin{array}{l}\text { Ipatasertib in Combination with Carboplatin, Carboplatin/Paclitaxel, or Capecitabine/Atezolizumab in Treating } \\
\text { Patients with Metastatic Triple-Negative Breast Cancer / Phases } 1 \text { and } 2\end{array}$ & Metastatic \\
\hline & Atezolizumab + Pertuzumab + Trastuzumab in CNS Mets in BC / Phase 2 & Metastatic \\
\hline & $\begin{array}{l}\text { Cryoablation, Atezolizumab/Nab-Paclitaxel for Locally Advanced or Metastatic Triple-Negative Breast Cancer / } \\
\text { Phase } 1\end{array}$ & Metastatic \\
\hline & $\begin{array}{l}\text { Olaparib with or without Atezolizumab in Treating Patients with Locally Advanced Unresectable or Metastatic Non- } \\
\text { HER2-Positive Breast Cancer / Phase } 2\end{array}$ & Metastatic \\
\hline & $\begin{array}{l}\text { Atezolizumab, Cobimetinib, and Eribulin in Treating Patients with Chemotherapy-Resistant Metastatic Inflammatory } \\
\text { Breast Cancer / Phase } 2\end{array}$ & Metastatic \\
\hline & $\begin{array}{l}\text { Testing the Drug Atezolizumab or Placebo with Usual Therapy in First-Line HER2-Positive Metastatic Breast } \\
\text { Cancer / Phase } 3\end{array}$ & Metastatic \\
\hline & $\begin{array}{l}\text { A Study of Multiple Immunotherapy-Based Treatment Combinations in Hormone Receptor (HR)-Positive Human } \\
\text { Epidermal Growth Factor Receptor } 2 \text { (HER2)-Negative Breast Cancer / Phases } 1 \text { and } 2\end{array}$ & Metastatic \\
\hline
\end{tabular}


Table 1 (continued)

\begin{tabular}{|c|c|c|}
\hline Agent & Trial / Phase & Setting \\
\hline & $\begin{array}{l}\text { Evaluation of IPI- } 549 \text { Combined with Front-Line Treatments in Pts. with Triple-Negative Breast Cancer or Renal Cell } \\
\text { Carcinoma (MARIO-3) / Phase } 2\end{array}$ & Metastatic \\
\hline & $\begin{array}{l}\text { Tesetaxel Plus } 3 \text { Different PD-(L)1 Inhibitors in Patients with Metastatic TNBC and Tesetaxel Monotherapy in } \\
\text { Patients with HER2-Negative MBC / Phase } 2\end{array}$ & Metastatic \\
\hline & $\begin{array}{l}\text { A Study Evaluating the Efficacy and Safety of Multiple Immunotherapy-Based Treatment Combinations in Patients } \\
\text { with Metastatic or Inoperable Locally Advanced Triple-Negative Breast Cancer / Phases } 1 \text { and } 2\end{array}$ & Metastatic \\
\hline & $\begin{array}{l}\text { Radiation Therapy and M7824 in Treating Patients with Metastatic Hormone Receptor-Positive, HER2-Negative } \\
\text { Breast Cancer / Phase } 1\end{array}$ & Metastatic \\
\hline & $\begin{array}{l}\text { A Study of RO7198457 as a Single Agent and in Combination with Atezolizumab in Participants with Locally } \\
\text { Advanced or Metastatic Tumors / Phase } 1\end{array}$ & Metastatic \\
\hline & $\begin{array}{l}\text { Study of Cabozantinib in Combination with Atezolizumab to Subjects with Locally Advanced or Metastatic Solid } \\
\text { Tumors / Phases } 1 \text { and } 2\end{array}$ & Metastatic \\
\hline & Safety and Efficacy of KY1044 and Atezolizumab in Advanced Cancer / Phases 1 and 2 & Metastatic \\
\hline & M7824 and Eribulin Mesylate in Treating Patients with Metastatic Triple-Negative Breast Cancer / Phase 1 & Metastatic \\
\hline & $\begin{array}{l}\text { FT500 as Monotherapy and in Combination with Immune Checkpoint Inhibitors in Subjects with Advanced Solid } \\
\text { Tumors / Phase } 1\end{array}$ & Metastatic \\
\hline & Focused Ultrasound Ablation and PD-1 Antibody Blockade in Advanced Solid Tumors / Phase 1 & Metastatic \\
\hline \multirow[t]{11}{*}{ Durvalumab } & $\begin{array}{l}\text { Phase II Multicenter Study of Durvalumab and Olaparib in Platinum-Treated Advanced Triple-Negative Breast } \\
\text { Cancer (DORA) / Phase } 2\end{array}$ & Metastatic \\
\hline & $\begin{array}{l}\text { Durvalumab (MEDI4736) and Tremelimumab in Hormone Receptor-Positive, Hypermutated Metastatic Breast } \\
\text { Cancer Identified by Whole Exome Sequencing / Phase } 2\end{array}$ & Metastatic \\
\hline & $\begin{array}{l}\text { Paclitaxel + Carboplatin + Durvalumab with or without Oleclumab for Previously Untreated Locally Recurrent } \\
\text { Inoperable or Metastatic TNBC / Phases } 1 \text { and } 2\end{array}$ & Metastatic \\
\hline & Durvalumab, with Olaparib and Fulvestrant in Advanced ER+, HER2- Breast Cancer Patients / Phase 2 & Metastatic \\
\hline & A Study of Novel Anti-Cancer Agents in Patients with Metastatic Triple-Negative Breast Cancer / Phases 1 and 2 & Metastatic \\
\hline & MEDI4736 and Tremelimumab in Treating Patients with Metastatic HER2-Negative Breast Cancer / Phase 2 & Metastatic \\
\hline & Olaparib and Durvalumab to Treat Patients with Metastatic Triple-Negative Breast Cancer / Phase 2 & Metastatic \\
\hline & $\begin{array}{l}\text { Phase I/II Study of the Anti-Programmed Death Ligand-1 Antibody MEDI } 4736 \text { in Combination with Olaparib and/or } \\
\text { Cediranib for Advanced Solid Tumors and Advanced or Recurrent Ovarian, Triple-Negative Breast, Lung, Prostate } \\
\text { and Colorectal Cancers / Phases } 1 \text { and } 2\end{array}$ & Metastatic \\
\hline & Dose Escalation Study of mRNA-2752 for Intratumoral Injection to Patients with Advanced Malignancies / Phase 1 & Metastatic \\
\hline & $\begin{array}{l}\text { A Phase 1/2 Study of in situ Vaccination with Tremelimumab and IV Durvalumab plus PolyICLC in Subjects with } \\
\text { Advanced, Measurable, Biopsy-Accessible Cancers / Phases } 1 \text { and } 2\end{array}$ & Metastatic \\
\hline & $\begin{array}{l}\text { Naptumomab Estafenatox in Combination with Durvalumab in Subjects with Selected Advanced or Metastatic Solid } \\
\text { Tumors / Phase } 1\end{array}$ & Metastatic \\
\hline
\end{tabular}

sectable, locally advanced, or metastatic triple-negative breast cancer, with PD-L1-stained tumor-infiltrating immune cells of any intensity covering $\geq 1 \%$ of the tumor area. Two ongoing studies are evaluating the use of ICI plus chemotherapy in patients with early $(<12$ months after [neo] adjuvant chemotherapy) relapse who were ineligible for the Impassion 130 study $[18,19]$. KEYNOTE-355 is a phase 3 study assessing the use of pembrolizumab or placebo in combination with each of 3 investigator-selected chemotherapies (nab-paclitaxel, paclitaxel, and gemcitabine/carboplatin) for first-line treatment of locally recurrent inoperable or metastatic triple-negative breast cancer with relapse $<6$ months after the initial diagnosis, according to PD-L1 expression (no expression, combined positive score $\geq 1$, and combined positive score $\geq 10$ ) [18]. That study is currently recruiting patients, but an interim analysis revealed a significant and clinically meaningful improvement in PFS in patients receiving pembrolizumab relative to those receiving chemotherapy, with a safety profile consistent with previously published data $[20,21]$. Impassion 132 is enrolling a similar group of patients with relapse $\leq 12$ months after 
curative-intent chemotherapy, with the comparison of atezolizumab or placebo with the investigators' choice of chemotherapy (gemcitabine plus carboplatin or capecitabine) [19]. In addition to the question of which chemotherapeutic backbone will be the optimal partner for ICI combination therapy, the timing of chemotherapy is being examined. Given the rationale that chemotherapy has immunostimulatory effects, but also leads to lymphodepletion, the combined administration of ICI with low-dose induction chemotherapy is an approach that has shown promising results in early-phase clinical trials [22]. Similarly, the SAFIR-02 trial demonstrated that ICI maintenance monotherapy following a response to induction chemotherapy can significantly improve survival relative to the continuation of chemotherapy in patients with metastatic triple-negative PD-L1-positive breast cancer [23]. Regarding biomarkers for treatment response, line of treatment and PD-1/L1 expression seem to be the most suitable to date in the metastatic setting, with patients receiving first-line ICI and those with PD-1/ L1-positive tumors benefitting the most from ICI therapy. Several ongoing clinical trials are assessing combination therapies with different ICI or ICI and other immunogenic agents (Table 1).

\section{Early Breast Cancer}

The observation that PD-1/L1 expression and the number of TIL are greater in early-stage versus metastatic breast cancer, and promising results from phases 1 and 2 studies, have provided the rationale for evaluation of ICI in the neoadjuvant setting [24-26]. The recently presented phase 3 KEYNOTE-522 study assessed the effects of pembrolizumab (200 mg, 4 cycles, i.v.) and placebo every 3 weeks plus neoadjuvant chemotherapy with $12 \times$ paclitaxel $\left(80 \mathrm{mg} / \mathrm{m}^{2}\right)$ and carboplatin (area under the curve $[A U C]=5$, every 3 weeks or $1.5 \mathrm{mg} / \mathrm{mL} / \mathrm{min}$ once weekly), followed by 4 cycles of pembrolizumab or placebo plus doxorubicin $\left(60 \mathrm{mg} / \mathrm{m}^{2}\right)$ or epirubicin $\left(90 \mathrm{mg} / \mathrm{m}^{2}\right)$ plus cyclophosphamide $\left(600 \mathrm{mg} / \mathrm{m}^{2}\right)$ every 3 weeks in 1,174 patients with newly diagnosed triple-negative breast cancer [27]. Pathologic complete response (pCR) rates were $64.8 \%$ (95\% CI 59.9-69.5) in the pembrolizumab arm and 51.2\% (95\% CI 44.1-58.3) in the placebo arm $(p<0.001)$. This effect was strongest in patients with node-positive disease and more advanced tumor stages, and it was independent of PD-L1 expression. Grade 3+ adverse events occurred in $76.8 \%$ of patients in the pembrolizumab arm and in $72.2 \%$ of those in the placebo arm, and discontinuation of any trial drug due to treatmentrelated adverse events occurred in 23.3 and $12.3 \%$ of cases, respectively [27].

A similar study (NeoTRIP) assessed the effects of 8 cycles of atezolizumab (1,200 mg i.v. every 3 weeks) or placebo plus neoadjuvant chemotherapy with 8 cycles of carboplatin (AUC $=2$, i.v., on days 1 and 8 every 3 weeks) and nab-paclitaxel $\left(125 \mathrm{mg} / \mathrm{m}^{2}\right.$ i.v. on days 1 and 8 every 3 weeks), followed by definite breast surgery and 4 cycles of doxorubicin $\left(60 \mathrm{mg} / \mathrm{m}^{2}\right)$ or epirubicin $\left(90 \mathrm{mg} / \mathrm{m}^{2}\right)$ plus cyclophosphamide $\left(600 \mathrm{mg} / \mathrm{m}^{2}\right)$ every 3 weeks in 280 women with triple-negative breast cancer [28]. The pCR rate did not differ significantly between the atezolizumab $(43.5 \%)$ and placebo (40.8\%) arms in the ITT analysis. Among PD-L1-positive patients, the pCR rate was higher in the atezolizumab group (51.9\%) compared to the placebo group (48\%), but this difference was not significant. However, PD-L1-positive status was the only variable associated with the $\mathrm{pCR}$ rate in the multivariate analysis $(p<0.01)$ [28]. The results of these 2 neoadjuvant chemotherapy studies seem to conflict, but correct interpretation of the outcomes requires consideration of differences in study design, primary endpoints (pCR in KEYNOTE-522 vs. event-free survival in NeoTRIP), and chemotherapy timing (before surgery in KEYNOTE-522 vs. after surgery in NeoTRIP). Further analyses of the long-term NeoTRIP outcomes will show whether atezolizumab plus the chemotherapy combination has a role in the neoadjuvant setting. The importance of immunotherapy timing was demonstrated in the phase 2 GeparNuevo trial, which assessed the effects of neoadjuvant durvalum$\mathrm{ab}$ (1.5 g i.v. every 4 weeks) or placebo plus nab-paclitaxel (125 mg/m $\mathrm{m}^{2}$ weekly for 12 weeks), followed by 4 cycles of epirubicin/cyclophosphamide $\left(90 / 600 \mathrm{mg} / \mathrm{m}^{2}\right.$ every 2 weeks) [29]. The trial also included a "window cohort" that received durvalumab or placebo monotherapy 2 weeks before the initiation of chemotherapyIn the ITT population; the pCR rate did not differ significantly between patients receiving durvalumab $(53.4 \%$; $95 \% \mathrm{CI}$ $42.5-61.4)$ and those receiving a placebo (44.2\%; $95 \%$ CI 33.5-55.3); in the window cohort, however, the pCR rate was significantly higher in patients treated with durvalumab (61\%) compared to the placebo arm $(41.4 \% ; p=$ $0.035)$. Several ongoing neoadjuvant, adjuvant, and postneoadjuvant chemotherapy trials are further evaluating the role of ICI in breast cancer treatment (Table 2).

\section{Other ICI}

Proteins other than PD-1/PD-L1 that might be targetable with checkpoint inhibitors have been identified; they include lymphocyte-activation gene 3, B7-H4, and T-cell immunoreceptor with immunoglobulin (Ig) and immunoreceptor tyrosine-based inhibition motif domains (TIGIT) [4]. The use of these ICI in combination with PD-L1 ICI is currently being studied in phase 1 trials for solid tumors, and studies for breast cancer are planned [30]. Another possible ICI target is CTL-associated antigen 4 (CTLA-4), which can limit T-cell activation by interaction with its ligand, CD80, or CD86. Increased T-cell activation due to CTLA-4 inhibition has been shown to 
Table 2. Immune checkpoint inhibitor trials for breast cancer in the recruitment phase

\begin{tabular}{|c|c|c|}
\hline Agent & Trial / Phase & Setting \\
\hline \multirow[t]{16}{*}{ Pembrolizumab } & Breast Cancer Study of Preoperative Pembrolizumab + Radiation / Phase 1 & Neoadjuvant \\
\hline & $\begin{array}{l}\text { A Study of Changes in PD-L1 Expression during Preoperative Treatment with Nab-Paclitaxel and } \\
\text { Pembrolizumab in Hormone Receptor-Positive Breast Cancer / Phase } 1\end{array}$ & Neoadjuvant \\
\hline & $\begin{array}{l}\text { Effects of MK-3475 (Pembrolizumab) on the Breast Tumor Microenvironment in Triple-Negative Breast } \\
\text { Cancer / Phase } 1\end{array}$ & Neoadjuvant \\
\hline & $\begin{array}{l}\text { Study of Immunotherapy in Combination with Chemotherapy in HER2-Negative Inflammatory Breast } \\
\text { Cancer / Phase } 2\end{array}$ & Neoadjuvant \\
\hline & $\begin{array}{l}\text { Neoadjuvant Phase } 2 \text { Study of Pembrolizumab and Carboplatin plus Docetaxel in Triple-Negative Breast } \\
\text { Cancer / Phase } 2\end{array}$ & Neoadjuvant \\
\hline & Neoadjuvant Her2-Targeted Therapy and Immunotherapy with Pembrolizumab / Phase 2 & Neoadjuvant \\
\hline & $\begin{array}{l}\text { Neoadjuvant Pembrolizumab + Decitabine Followed by Std Neoadj Chemo for Locally Advanced HER2- Breast } \\
\text { Ca / Phase } 2\end{array}$ & Neoadjuvant \\
\hline & I-SPY 2 TRIAL: Neoadjuvant and Personalized Adaptive Novel Agents to Treat Breast Cancer / Phase 2 & Neoadjuvant \\
\hline & Pembrolizumab in High-Risk Ductal Carcinoma in situ (DCIS) / Phase 1 & Neoadjuvant \\
\hline & $\begin{array}{l}\text { Study of Pembrolizumab (MK-3475) versus Placebo in Combination with Neoadjuvant Chemotherapy and } \\
\text { Adjuvant Endocrine Therapy in the Treatment of Early-Stage Estrogen Receptor-Positive, Human Epidermal } \\
\text { Growth Factor Receptor 2-Negative (ER+/HER2-) Breast Cancer (MK-3475-756/KEYNOTE-756) / Phase } 3\end{array}$ & $\begin{array}{l}\text { Neoadjuvant/ } \\
\text { adjuvant }\end{array}$ \\
\hline & $\begin{array}{l}\text { Pembrolizumab in Treating Patients with Hormone Receptor-Positive, Localized Inflammatory Breast Cancer } \\
\text { Who Are Receiving Hormone Therapy and Did Not Achieve a Pathological Complete Response to } \\
\text { Chemotherapy / Phase } 2\end{array}$ & Adjuvant \\
\hline & Testing MK-3475 (Pembrolizumab) as Adjuvant Therapy for Triple Receptor-Negative Breast Cancer / Phase 3 & Adjuvant \\
\hline & $\begin{array}{l}\text { Pembrolizumab with Carboplatin Compared to Carboplatin Alone in Breast Cancer Patients with Chest Wall } \\
\text { Disease / Phase } 2\end{array}$ & $\begin{array}{l}\text { Adjuvant/ } \\
\text { metastatic }\end{array}$ \\
\hline & $\begin{array}{l}\text { Study of GX-I7 in Combination with Pembrolizumab in Refractory or Relapsed (R/R) TNBC Subjects(GX-I7- } \\
\text { CA-006/KEYNOTE-899) / Phases } 1 \text { and } 2\end{array}$ & $\begin{array}{l}\text { Adjuvant/ } \\
\text { metastatic }\end{array}$ \\
\hline & $\begin{array}{l}\text { Pembrolizumab in Treating Patients with Stage IV Metastatic or Recurrent Inflammatory Breast Cancer or } \\
\text { Triple-Negative Breast Cancer Who Have Achieved Clinical Response or Stable Disease to Prior Chemotherapy / } \\
\text { Phase } 2\end{array}$ & $\begin{array}{l}\text { Adjuvant/ } \\
\text { metastatic }\end{array}$ \\
\hline & $\begin{array}{l}\text { Galinpepimut-S in Combination with Pembrolizumab in Patients with Selected Advanced Cancers / Phases } 1 \\
\text { and } 2\end{array}$ & $\begin{array}{l}\text { Adjuvant/ } \\
\text { metastatic }\end{array}$ \\
\hline \multirow[t]{10}{*}{ Nivolumab } & $\begin{array}{l}\text { Peri-Operative Ipilimumab+Nivolumab and Cryoablation versus Standard Care in Women with Triple-Negative } \\
\text { Breast Cancer / Phase } 2\end{array}$ & Neoadjuvant \\
\hline & $\begin{array}{l}\text { Trial of Nivolumab with Chemotherapy as Neoadjuvant Treatment in Inflammatory Breast Cancer (IBC) / } \\
\text { Phase } 2\end{array}$ & Neoadjuvant \\
\hline & $\begin{array}{l}\text { A Study of Neoadjuvant Nivolumab + Palbociclib + Anastrozole in Post-Menopausal Women and Men with } \\
\text { Primary Breast Cancer / Phase } 2\end{array}$ & Neoadjuvant \\
\hline & $\begin{array}{l}\text { Ipilimumab, Nivolumab, and Talimogene Laherparepvec before Surgery in Treating Participants with Localized, } \\
\text { Triple-Negative or Estrogen Receptor-Positive, HER2-Negative Breast Cancer-Deleted / Phase } 1\end{array}$ & Neoadjuvant \\
\hline & Study of Nivolumab versus Placebo in Participants with High-Risk Breast Cancer / Phase 3 & $\begin{array}{l}\text { Neoadjuvant/ } \\
\text { adjuvant }\end{array}$ \\
\hline & $\begin{array}{l}\text { OXEL: Immune Checkpoint or Capecitabine or Combination Therapy as Adjuvant Therapy for TNBC with } \\
\text { Residual Disease / Phase } 2\end{array}$ & Adjuvant \\
\hline & $\begin{array}{l}\text { TPST-1120 as Monotherapy and in Combination with (Nivolumab, Docetaxel or Cetuximab) in Subjects with } \\
\text { Advanced Cancers / Phase } 1\end{array}$ & $\begin{array}{l}\text { Adjuvant/ } \\
\text { metastatic }\end{array}$ \\
\hline & COM701 in Subjects with Advanced Solid Tumors / Phase 1 & $\begin{array}{l}\text { Adjuvant/ } \\
\text { metastatic }\end{array}$ \\
\hline & Nivolumab and Ipilimumab in Treating Patients with Rare Tumors / Phase 2 & $\begin{array}{l}\text { Adjuvant/ } \\
\text { metastatic }\end{array}$ \\
\hline & $\begin{array}{l}\text { FT500 as Monotherapy and in Combination with Immune Checkpoint Inhibitors in Subjects with Advanced } \\
\text { Solid Tumors / Phase } 1\end{array}$ & $\begin{array}{l}\text { Adjuvant/ } \\
\text { metastatic }\end{array}$ \\
\hline
\end{tabular}


Table 2 (continued)

\begin{tabular}{|c|c|c|}
\hline Agent & Trial / Phase & Setting \\
\hline & $\begin{array}{l}\text { Targeted Therapy Directed by Genetic Testing in Treating Patients with Advanced Refractory Solid Tumors, } \\
\text { Lymphomas, or Multiple Myeloma (the MATCH Screening Trial) / Phase } 2\end{array}$ & $\begin{array}{l}\text { Adjuvant/ } \\
\text { metastatic }\end{array}$ \\
\hline \multirow[t]{13}{*}{ Atezolizumab } & $\begin{array}{l}\text { Clinical Trial of Neoadjuvant Chemotherapy with Atezolizumab or Placebo in Patients with Triple-Negative } \\
\text { Breast Cancer Followed after Surgery by Atezolizumab or Placebo / Phase } 3\end{array}$ & Neoadjuvant \\
\hline & $\begin{array}{l}\text { A Study to Evaluate the Efficacy and Safety of Atezolizumab or Placebo in Combination with Neoadjuvant } \\
\text { Doxorubicin + Cyclophosphamide Followed by Paclitaxel + Trastuzumab + Pertuzumab in Early Her2-Positive } \\
\text { Breast Cancer / Phase } 3\end{array}$ & Neoadjuvant \\
\hline & Neoadjuvant Treatment of HER2-Positive Early High-Risk and Locally Advanced Breast Cancer / Phase 3 & Neoadjuvant \\
\hline & Nab-Paclitaxel and Atezolizumab before Surgery in Treating Patients with Triple-Negative Breast Cancer / Phase 2 & Neoadjuvant \\
\hline & Pre-Operative Immunotherapy Combination Strategies in Breast Cancer / Phase 2 & Neoadjuvant \\
\hline & $\begin{array}{l}\text { Improving Pre-Operative Systemic Therapy for Human Epidermal Growth Factor Receptor } 2 \text { (HER2)-Amplified } \\
\text { Breast Cancer / Phase II }\end{array}$ & Neoadjuvant \\
\hline & A Window-of-Opportunity Study of Pelareorep in Early Breast Cancer / Phase 1 & Neoadjuvant \\
\hline & $\begin{array}{l}\text { A Study to Describe the Diagnosis, Anti-Cancer Treatment and Clinical Outcome in Patients with Newly } \\
\text { Diagnosed Breast Cancer in Latin America }\end{array}$ & Neoadjuvant \\
\hline & M7824 in Treating Patients with Stage II-III HER2-Positive Breast Cancer / Phase 1 & Neoadjuvant \\
\hline & Combination of Talimogene Laherparepvec with Atezolizumab in Early Breast Cancer / Phase 1 & Adjuvant \\
\hline & $\begin{array}{l}\text { A Study Comparing Atezolizumab (Anti PD-L1 Antibody) in Combination with Adjuvant Anthracycline/ } \\
\text { Taxane-Based Chemotherapy versus Chemotherapy Alone in Patients with Operable Triple-Negative Breast } \\
\text { Cancer / Phase } 3\end{array}$ & Adjuvant \\
\hline & $\begin{array}{l}\text { Efficacy and Safety of Atezolizumab plus Capecitabine Adjuvant Therapy for Triple Receptor-Negative Breast } \\
\text { Cancer / Phase } 2\end{array}$ & Adjuvant \\
\hline & PRS-343 in Combination with Atezolizumab in HER2-Positive Solid Tumors / Phase 1 & $\begin{array}{l}\text { Adjuvant/ } \\
\text { metastatic }\end{array}$ \\
\hline \multirow[t]{10}{*}{ Durvalumab } & Durvalumab with Trastuzumab and Pertuzumab in HER2-Enriched Breast Cancer / Phase 2 & Neoadjuvant \\
\hline & $\begin{array}{l}\text { Safety and Efficacy of Durvalumab Combined to Neoadjuvant Chemotherapy in Localized Luminal B HER2(-) } \\
\text { and Triple-Negative Breast Cancer / Phases } 1 \text { and } 2\end{array}$ & Neoadjuvant \\
\hline & $\begin{array}{l}\text { Neoadjuvant MEDI4736 Concomitant with Weekly Nab-Paclitaxel and Dose-Dense AC for Stage I-III Triple- } \\
\text { Negative Breast Cancer / Phases } 1 \text { and } 2\end{array}$ & Neoadjuvant \\
\hline & $\begin{array}{l}\text { Window-of-Opportunity Trial of Neoadjuvant Olaparib and Durvalumab for Triple-Negative or Low ER+ Breast } \\
\text { Cancer / Phases } 1 \text { and } 2\end{array}$ & Neoadjuvant \\
\hline & Aromatase Inhibitor and Durvalumab in Postmenopausal Breast Cancer / Phase 2 & Neoadjuvant \\
\hline & $\begin{array}{l}\text { Neo-Adjuvant Chemotherapy Combined with Stereotactic Body Radiotherapy to the Primary Tumour +/- } \\
\text { Durvalumab, +/- Oleclumab in Luminal B Breast Cancer / Phase } 2\end{array}$ & Neoadjuvant \\
\hline & $\begin{array}{l}\text { PHOENIX DDR/Anti-PD-L1 Trial: A Pre-Surgical Window-of-Opportunity and Post-Surgical Adjuvant } \\
\text { Biomarker Study of DNA Damage Response Inhibition and/or Anti-PD-L1 Immunotherapy in Patients with } \\
\text { Neoadjuvant Chemotherapy-Resistant Residual Triple-Negative Breast Cancer / Phase } 2\end{array}$ & Neoadjuvant \\
\hline & I-SPY 2 TRIAL: Neoadjuvant and Personalized Adaptive Novel Agents to Treat Breast Cancer / Phase 2 & Neoadjuvant \\
\hline & $\begin{array}{l}\text { Neoantigen DNA Vaccine Alone vs. Neoantigen DNA Vaccine plus Durvalumab in Triple-Negative Breast } \\
\text { Cancer Patients following Standard of Care Therapy / Phase } 1\end{array}$ & Adjuvant \\
\hline & $\begin{array}{l}\text { Ascending Doses of Ceralasertib in Combination with Chemotherapy and/or Novel Anti-Cancer Agents / Phases } \\
1 \text { and } 2\end{array}$ & $\begin{array}{l}\text { Adjuvant/ } \\
\text { metastatic }\end{array}$ \\
\hline
\end{tabular}

have antitumoral effects [31, 32]. Two monoclonal antibodies, i.e., tremelimumab and ipilimumab, have been assessed clinically. A phase I study evaluated tremelimumab (3-10 mg/kg i.v. every 4 weeks for 3 months) plus exemestane ( $25 \mathrm{mg}$ orally daily) in 26 patients with advanced hormone receptor-positive breast cancer [33]. The best overall response was stable disease at $\geq 12$ weeks in 11 (42\%) patients, with a tolerable safety profile [33]. Ipilimumab has been approved by the FDA for the treatment of metastatic melanoma, and its use for breast cancer has 
been assessed in early clinical phase studies. A pilot study evaluated preoperative treatment with tumor cryoablation and/or single-dose ipilimumab (10 mg/kg i.v.) in 19 patients undergoing mastectomy [34]. The researchers examined safety, tolerability, and immune activation and found both individual treatments and their combination to be safe, with intratumoral and systemic immunological effects [34]. Other trials assessing the use of chemotherapy plus multiple ICI combination therapies for metastatic breast cancer are currently underway (Table 2).

\section{ICI Combination Therapies}

ICI Plus Chemotherapy. Most clinical data on combination therapies are for ICI combined with chemotherapy, including those generated in the above mentioned large clinical studies IMPASSION130 and KEYNOTE-355, which showed durable response rates and increased survival outcomes $[17,18]$. The molecular mechanisms underlying this positive synergistic effect are not understood precisely, but they are based on complex drug- and dose-dependent interactions between chemotherapeutic agents and the immune system. These interactions include chemotherapy-induced cytotoxic immune responses, induction of proinflammatory cytokine secretion, inhibition of myeloid-derived suppressor cells, upregulation of receptors enhancing tumor cell susceptibility to lysis by natural killer cells, and recruitment and activation of immune cells such as dendritic, natural killer, and T cells. Several ongoing trials are seeking to determine the optimal chemotherapeutic agents to combine with ICI and the optimal sequence of application (Tables 1,2) [35-39].

ICI Plus Anti-HER2 Targeted Therapy. Several other attempts to add immunotherapy to established treatment regimens have been made. Targeted therapeutic agents, such as the anti-HER2 antibody trastuzumab, have been found to mediate antitumoral activity, partly through the modulation of immune activity, and thus might be beneficial when used in combination with immunotherapeutic agents $[40,41]$. The single-arm phase IB/2 PANACEA study evaluated the effects of trastuzumab $(6 \mathrm{mg} / \mathrm{kg}$ i.v. every 3 weeks) combined with pembrolizumab $(200 \mathrm{mg}$ i.v. every 3 weeks) in patients with advanced HER2-positive breast cancer who had progressed during trastuzumab-based therapy, according to PD-L1 status [42]. Six out of $40(15 \%)$ patients in the PD-L1-positive cohort and none of 12 patients in the PD-L1-negative cohort showed an objective response. Pembrolizumab was tolerated well and the antitumoral activity was durable, with a median treatment response duration of 11.2 months (range: 6.2 to not reached) [42]. In a similar phase 1 trial assessing the effects of the ICI durvalumab $(1,125 \mathrm{mg}$ i.v. every 3 weeks) combined with trastuzumab $(6 \mathrm{mg} / \mathrm{kg}$ i.v. every 3 weeks) in extensively pretreated patients with metastatic
HER2-positive breast cancer, the researchers observed no objective response to therapy and all 15 patients had $<1 \%$ PD-L1 expression [43]. The KATE2 trial also demonstrated the dependency of antitumoral activity induced by ICI combination therapy on the PD-L1 expression status [44]. This phase 2 study was the first to compare the effects of the ICI atezolizumab $(1,200 \mathrm{mg}$ i.v. every 2 weeks) plus the antibody drug conjugate trastuzumab emtansine $(3.6 \mathrm{mg} / \mathrm{kg}$ i.v. every 3 weeks) with those of trastuzumab emtansine $(3.6 \mathrm{mg} / \mathrm{kg}$ every 3 weeks) alone in 202 patients with advanced or metastatic HER2-positive breast cancer who progressed after trastuzumabbased treatment, stratified by PD-L1 immune cell status $(<1$ vs. $\geq 1 \%$ ). In the ITT population, PFS and OS did not differ significantly between groups. In the subgroup of PD-L1-positive patients, however, PFS and 1-year OS were numerically greater in the combined therapy group (PFS $=8.5$ months, range: 5.7 to not evaluated, $\mathrm{HR}=0.60$; $95 \%$ CI $0.32-1.11 ; 1$-year OS $=94.3 \%, \mathrm{HR}=0.55 ; 95 \% \mathrm{CI}$ $0.22-1.38$ ) compared to the trastuzumab emtansine group [PFS $=4.1$ months, range: $2.7-11.1 ; 1$-year OS = 87.9\%) [44]. These trials show that ICI plus anti-HER2 targeted therapy has a potential role in the treatment of PD-L1-positive tumors, but their samples are small and this research is in an early phase. Larger, ongoing clinical trials assessing this therapeutic approach will aid in the assessment of its effectiveness (Table 1).

ICI Plus Poly(ADP-Ribose) Polymerase Inhibitors. Olaparib and talazoparib are the 2 poly(ADP-ribose) polymerase (PARP) inhibitors that have been approved for the treatment of patients with metastatic breast cancer with germline BRCA1 or 2 mutations. As BRCA loss of function causes altered homologous recombination, these tumors with DNA repair deficiencies are highly susceptible to genomic instability, leading to the activation of intracellular cytotoxic interferon (IFN) genes and the accumulation of immunogenic neoantigens $[45,46]$. In vivo experiments conducted with breast cancer cell lines and animal models have shown that treatment with PARP inhibitors leads to upregulation of PD-L1 expression [45, $47,48]$. These findings provided the rationale for the first clinical studies assessing ICI plus PARP inhibitor therapeutic combinations. The MEDIOLA trial, a single-arm phase $1 / 2$ basket study, evaluated the effects of treatment with olaparib (300 mg orally, twice a day, for 4 weeks) followed by olaparib plus durvalumab ( $15 \mathrm{mg}$ i.v. every 4 weeks) in patients with metastatic HER2-negative, germline BRCA-mutated solid tumors [49]. Disease control was achieved at 28 weeks in 15 out of 30 patients (50\%), with a tolerable safety profile [49]. Similarly, the TOPACIO/KEYNOTE-162 study, an open-label phase 2 trial, evaluated the combination of niraparib (200 mg orally) and pembrolizumab ( $200 \mathrm{mg}$ i.v. every 3 weeks) in patients with advanced or metastatic triple-negative breast 
cancer. The overall response rate (ORR) in the whole cohort was $21 \%$, and response rates were greater among patients with BRCA mutations (47\%) and those with PD-L1positive tumors (32\%) than among those without BRCA mutation (11\%) and PD-L1-negative patients (8\%), respectively. These findings suggest the existence of synthetic lethal interaction with PARP inhibitor-ICI combination therapy, which might be most effective in PD-L1positive patients, but it would be premature to draw definite conclusions at this stage of research. Additional studies are underway to further explore this possibility (Table 1) [50].

ICI plus Cyclin-Dependent Kinases 4/6 Inhibitors. Cyclin-dependent kinase 4/6 (CDK4/6) inhibitors have shown significant clinical activity in patients with metastatic hormone receptor-positive, HER2-negative breast cancer [51-53]. Although their antitumoral effect is achieved primarily by the suppression of retinoblastoma phosphorylation, which leads to cell cycle arrest and inhibition of cell proliferation, they also enhance tumor immunogenicity [54-56]. Thus, a possible synergistic effect of combination therapy with ICI has been proposed. An initial phase $1 / 2$ study assessed the effect of the CDK4/6 inhibitor abemaciclib (150 mg orally twice a day) plus pembrolizumab (200 mg i.v. every 3 weeks) in 28 patients with hormone receptor-positive, HER2-negative metastatic breast cancer [57]. At 24 weeks, the researchers observed an overall response rate of $14 \%$ (4 patients) and a manageable safety profile [57]. These results seem promising when compared with the $11 \%$ early response rate achieved with abemaciclib monotherapy in the MONARCH 1 trial [58], a phase 2 study of abemaciclib as a single agent used to treat refractory hormone receptorpositive, HER2-negative metastatic breast cancer.

ICI plus Other Immunotherapies. As the immune system is complex, intertwined, and multidimensional, the combination of ICI with other immunotherapies seems to be a promising approach to account for potential escape mechanisms and to increase the treatment effectiveness relative to monotherapy. Such combinations are applied with the goals of enhancing immune cell infiltration, increasing immune cell activity, and augmenting cancer antigen presentation [46]. The combined use of anti-CTLA-4 and anti-PD- 1 agents has been proven to be clinically effective and lead to durable response rates in patients with melanoma $[59,60]$. In these clinical trials, the combination of these 2 agents increased the toxicity, but also the response rate, relative to monotherapy. A single-arm study assessed the effects of the anti-PD-L1 agent durvalumab $(15 \mathrm{mg} / \mathrm{kg}$ i.v. every 4 weeks) combined with the antiCTLA- 4 agent tremelimumab ( $1 \mathrm{mg} / \mathrm{kg}$ i.v. every 4 weeks) in patients with metastatic hormone receptor-positive or triple-negative breast cancer [61]. Of the 18 enrolled patients ( 7 with triple-negative and 11 with hormone recep- tor-positive breast cancer), 3 (17\%) patients with triplenegative breast cancer showed an overall response ( $43 \%$ response rate for this subgroup). These results permit speculation about the possible role of this combination for patients with triple-negative breast cancer, but further trials are warranted to clarify these findings.

\section{Vaccine-Based Therapies}

Examination of the use of the immunoregulatory capacities of antigen-presenting cells for vaccination and induction of an immune response in patients with cancer was initiated decades ago [62]. In subsequent years, further developments such as next-generation sequencing and nanotechnology led to the development of new therapeutic and diagnostic options $[63,64]$. With these technologies, therapies based on sequencing of cancer cell DNA and encoding of tumor-specific mutations became possible [63]. Cancer treatment vaccines are based on the concept of strengthening the patient's immune system to fight cancer cells. The key to this approach is to enable immune cells to recognize the tumor and be activated through substances in cancer cells [65]. Such vaccines can be derived using different approaches. Tumor-specific antigens (neoantigens) that arise from cancer-specific mutations and are specific to tumor cells can be used, but most of these neoantigens are unique to individual patients, necessitating a personalize approach to vaccination therapy $[66,67]$. Another approach involves TAA, which are expressed mainly on cancer cells of specific cancer entities but may also be expressed at lower levels on normal cells. As T cells with a strong TAA affinity are normally removed by central and peripheral immune tolerance mechanisms, TAA-based vaccines must be sufficiently immunogenic to activate the remaining low-affinity TAA-reactive T cells $[68,69]$. In vitro and in vivo research has produced promising results regarding the application of this vaccination therapy to breast cancer [70]. Chablani et al. [71] reported a significant increase in tumor suppression capability after vaccination in murine breast cancer models. The first human studies on the use of personalized RNA mutanome vaccines in combination with PD-1 blockade therapy have been successful for melanoma [72]. Administration of an INVAC-1 vaccine to 26 patients with solid tumors ( 5 with breast cancer) led to stable disease in $58 \%$ of the patients, and $42 \%$ of the patients received multiple vaccinations (up to 12 cycles) because of an initial tumor regression [73].

A promising approach for breast cancer immunotherapy is represented by vaccines that use HER2-derived peptides as TAA. Mittendorf et al. [74] assessed the ability of vaccination with E75, a human leukocyte antigen (an A2/A3-restricted HER2 peptide), and granulocyte- 
macrophage colony-stimulating factor (GM-CSF) versus placebo to prevent disease recurrence in the adjuvant setting in patients with HER2-expressing breast cancer (immunohistochemistry [IHC] score 1-3). As they had determined that E75 vaccination safely and effectively elicited HER2-specific immunity in previous studies, they further examined dose escalation and schedule optimization according to lymph node status and the risk of disease recurrence in that phase $1 / 2$ clinical trial [75]. The disease-free survival (DFS) rate was $94.3 \%$ in the vaccinated group (106 patients) and $86.8 \%$ in the control group (76 patients; $p=0.08$ ). Subgroup analysis showed that the patients who benefited most from vaccination were those with positive lymph nodes (DFS $=90.2 \%$ [vaccinated] vs. 79.1\% [control]; $p=0.13$ ), a low HER2 expression (IHC score $1+$ or $2+$; DFS $=94 \%$ [vaccinated] vs. $79.4 \%$ [control]; $p=0.04$ ), or grade 1 or 2 tumor (DFS $=98.4 \%$ [vaccinated] vs. $86.0 \%$ [control]; $p=0.01$ ). The observation that the HER2 expression level affects the response to E75 vaccination, with patients with a low HER2 expression (IHC score $1+$ or $2+$ with fluorescence in situ hybridization [FISH] negativity) showing better immunological responses than patients with HER2-overexpressing tumors, has been reported previously and might guide further definition of the subgroups that benefit most from this vaccination therapy [76]. Given these promising results, Mittendorf at al. [77] conducted the PRESENT trial, a phase 3 study assessing the effects of vaccination with $1,000 \mu \mathrm{g}$ nelipepimut-S (NP-S/E75; monthly for 6 months, then every 6 months through 36 months) plus GM-CSF (250 $\mu \mathrm{g}$ subcutaneously) relative to a placebo in patients with T1-T3 low HER2-expressing (IHC score 1+ or 2+ with FISH negativity) node-positive breast cancer in the adjuvant setting, after completion of neoadjuvant or adjuvant chemotherapy. An interim analysis revealed no significant difference in DFS between the NP-S group (24 patients; $6.3 \%$ ) and the control group (37 patients; $0.8 \%$ ) [77]. Approximately half of the recurrences observed in this trial were diagnosed by protocol-specific annual imaging of asymptomatic patients, without biopsy confirmation, and $74 \%$ of these recurrences were seen in the NP-S group, which led to termination of the trial after a median follow-up period of 16.8 months. As recurrence occurred 3 times more frequently in the NP-S arm than in the control arm, the researchers suspected that it was related to vaccination, but whether it represents a form of pseudoprogression or a true vaccine induced-recurrence remains unknown.

In addition to "preventive vaccination," several attempts have been made to evaluate vaccination therapy in the metastatic setting. Miles et al. [78] conducted the largest phase 3 study to date assessing vaccination with sialyl-TN (STn) conjugated to the carrier protein keyhole limpet hemocyanin (KLH) versus placebo in 1,028 wom- en with metastatic breast cancer who had previously received chemotherapy and had shown a response or disease stability. STn is a carbohydrate epitope found on a variety of glycoproteins, including mucin 1 (MUC-1) [78]. It is expressed by various tumor cells and seems to have functional significance in tumor growth and metastasis. Increased STn expression has been associated with the progression and poor prognosis of breast cancer, and STn is believed to be an important TAA [79-83]. In the phase 3 trial, patients received 1 intravenous dose of cyclophosphamide $\left(300 \mathrm{mg} / \mathrm{m}^{2}\right) 3$ days before subcutaneous injection of $100 \mu \mathrm{g}$ STn-KLH or placebo at weeks 0, 2,5 , and 9 [84]. Subsequently, the vaccine or placebo was administered without cyclophosphamide monthly for 4 months and then quarterly until disease progression. The vaccine was tolerated well and induced a considerable immune response, as reflected by serum titers and IgM and IgG antibodies. However, no significant difference was observed between the vaccine and placebo groups in the time to progression ( 3.4 vs. 3 months) or OS (23.1 vs. 22.3 months) [84].

Given the observation in preclinical studies that the MUC-1 protein might act as an oncoprotein for the activation of estrogen receptor- $\alpha$ function [85], Ibrahim et al. [86] conducted a retrospective subgroup analysis of data from the study of Miles et al. [84] to determine whether patients who received concurrent STn-KLH and endocrine therapy benefitted from vaccination. In the subsect of patients receiving endocrine therapy $(n=350)$, the median OS was significantly longer in the vaccination group than in the placebo group (36.6 vs. 30.7 months; $p=$ $0.036)$. The response to vaccination therapy depended on the immune response; the median OS of patients with greater antibody responses (anti-oncostatin M IgG titers $>1: 320$ ) was significantly longer than that of patients with lesser responses ( 41.3 vs. 25.4 months; $p=0.0147$ ). Several other ongoing trials are further assessing the application of various promising vaccination therapies in early and metastatic disease (Table 3).

\section{Cellular Therapy}

Adoptive cell therapy is based on isolation of immune cells ( $\mathrm{T}$ cells in most cases) from a patient. These cells are then enriched ex vivo for tumor-specific cloning, expanded, activated, and autologously readministered to the patient [87, 88]. Zacharakis et al. [89] reported a case in which a patient with repeatedly treated metastatic hormone receptor-positive breast cancer showed durable disease regression for $>22$ months after the adoptive transfer of mutant protein-specific TIL in conjunction with interleukin-2 and checkpoint blockade. The concept of adoptive cell therapy using mutation-specific TIL for 
Table 3. Tumor vaccination trials for breast cancer in the recruitment phase

\begin{tabular}{|c|c|c|}
\hline Agents & Trial / Phase & Setting \\
\hline Dendritic cell vaccine (DC1) & $\begin{array}{l}\text { HER2-Directed Dendritic Cell Vaccine during Neoadjuvant Therapy of HER2+Breast Cancer / } \\
\text { Phase } 1\end{array}$ & Neoadjuvant \\
\hline Mammaglobin-A DNA vaccine & $\begin{array}{l}\text { Safety and Immune Response to a Mammaglobin-A DNA Vaccine in Breast Cancer Patients } \\
\text { Undergoing Neoadjuvant Endocrine Therapy / Phase } 1\end{array}$ & Neoadjuvant \\
\hline PVSRIPO & Examining Bioactivity of PVSRIPO in Invasive Breast Cancer / Phase 1 & Neoadjuvant \\
\hline V3-MOMMO & Open Label Immunotherapy Trial for Breast Cancer / Phase 2 & Neoadjuvant \\
\hline $\begin{array}{l}\text { Granulocyte-macrophage } \\
\text { colony-stimulating factor, } \\
\text { multi-epitope HER2 peptide } \\
\text { vaccine H2NVAC }\end{array}$ & $\begin{array}{l}\text { A Vaccine (H2NVAC) before Surgery for the Treatment of HER2-Expressing Ductal Carcinoma } \\
\text { in situ / Phase } 1\end{array}$ & Neoadjuvant \\
\hline Poly ICLC & $\begin{array}{l}\text { Safety and Immunogenicity of a Personalized Synthetic Long Peptide Breast Cancer Vaccine } \\
\text { Strategy in Patients with Persistent Triple-Negative Breast Cancer following Neoadjuvant } \\
\text { Chemotherapy / Phase } 2\end{array}$ & Adjuvant \\
\hline Neo-antigen pulsed dendritic cell & Breast Cancer Neoantigen Vaccination with Autologous Dendritic Cells / Phase 1 & Adjuvant \\
\hline $\begin{array}{l}\text { Neoantigen DNA vaccine } \\
\text { durvalumab }\end{array}$ & $\begin{array}{l}\text { Neoantigen DNA Vaccine Alone vs. Neoantigen DNA Vaccine plus Durvalumab in Triple- } \\
\text { Negative Breast Cancer Patients following Standard of Care Therapy / Phase } 1\end{array}$ & Adjuvant \\
\hline $\begin{array}{l}\text { P10s-PADRE with } \\
\text { MONTANIDE }{ }^{\mathrm{TM}} \text { ISA } 51 \text { VG }\end{array}$ & Vaccination of Triple-Negative Breast Cancer Patients / Phase 2 & Adjuvant \\
\hline $\begin{array}{l}\text { DC1 vaccine } \\
\text { WOKVAC vaccine }\end{array}$ & Vaccine to Prevent Recurrence in Patients with HER-2 Positive Breast Cancer / Phase 2 & Adjuvant \\
\hline $\begin{array}{l}\text { Cyclophosphamide } \\
\text { Multi-epitope folate receptor- } \alpha \\
\text { peptide vaccine }\end{array}$ & $\begin{array}{l}\text { Multi-Epitope Folate Receptor- } \alpha \text { Peptide Vaccine, GM-CSF, and Cyclophosphamide in Treating } \\
\text { Patients with Triple-Negative Breast Cancer / Phase } 2\end{array}$ & Adjuvant \\
\hline Typhoid vaccine & $\begin{array}{l}\text { Typhoid Vaccine in Testing Response to Immune Stress in Patients with Stage I-IIIA Breast } \\
\text { Cancer }\end{array}$ & Adjuvant \\
\hline $\begin{array}{l}\text { Pertuzumab } \\
\text { Sargramostim }\end{array}$ & $\begin{array}{l}\text { TPIV100 and Sargramostim for the Treatment of HER2-Positive, Stage II-III Breast Cancer in } \\
\text { Patients with Residual Disease after Chemotherapy and Surgery / Phase } 2\end{array}$ & Adjuvant \\
\hline $\begin{array}{l}\text { Activated CIK and CD3-MUC1 } \\
\text { bispecific antibody } \\
\text { cryotherapy }\end{array}$ & $\begin{array}{l}\text { Study of Activated Cytokine-Induced Killer Armed with Bispecific Antibody for Advanced Breast } \\
\text { Cancer / Phase } 2\end{array}$ & Adjuvant \\
\hline YE-NEO-001 & $\begin{array}{l}\text { QUILT-2.025 NANT Neoepitope Yeast Vaccine (YE-NEO-001): Adjuvant Immunotherapy } \\
\text { Using a Personalized Neoepitope Yeast-Based Vaccine to Induce T-Cell Responses in Subjects w/ } \\
\text { Previously Treated Cancers / Phase } 1\end{array}$ & Adjuvant \\
\hline $\begin{array}{l}\mathrm{CD} 105 / \mathrm{Yb}-1 / \mathrm{SOX} 2 / \mathrm{CDH} 3 / \mathrm{MDM} 2- \\
\text { polyepitope plasmid } \\
\text { DNA vaccine }\end{array}$ & Vaccine Therapy in Treating Patients with HER2-Negative Stage III-IV Breast Cancer / Phase 1 & $\begin{array}{l}\text { Adjuvant/ } \\
\text { metastatic }\end{array}$ \\
\hline HER2 DC1 vaccine & $\begin{array}{l}\text { Immune Response and Potential Booster for Patients Who Have Received HER2-Pulsed DC1 / } \\
\text { Phase } 2\end{array}$ & $\begin{array}{l}\text { Adjuvant/ } \\
\text { metastatic }\end{array}$ \\
\hline HER-2 vaccine & Vaccine Therapy in Treating Patients with Metastatic Solid Tumors / Phase 1 & $\begin{array}{l}\text { Adjuvant/ } \\
\text { metastatic }\end{array}$ \\
\hline $\begin{array}{l}\text { VRP-HER2 } \\
\text { Pembrolizumab }\end{array}$ & $\begin{array}{l}\text { A Study to Evaluate Concurrent VRP-HER2 Vaccination and Pembrolizumab for Patients with } \\
\text { Breast Cancer / Phase } 2\end{array}$ & Metastatic \\
\hline $\begin{array}{l}\text { AE37 peptide vaccine } \\
\text { Pembrolizumab }\end{array}$ & $\begin{array}{l}\text { Establishing the Recommended Biological Dose for AE37 Peptide Vaccine in Combination with } \\
\text { Pembrolizumab that Will Enhance the Tumor-Specific Immune Response and Demonstrate } \\
\text { Efficacy in Patients with Advanced Triple-Negative Breast Cancer / Phase } 2\end{array}$ & Metastatic \\
\hline PVX-410 pembrolizumab & $\begin{array}{l}\text { PVX-410 Vaccine plus Pembrolizumab in HLA-A2+ Metastatic Triple-Negative Breast Cancer / } \\
\text { Phase } 1\end{array}$ & Metastatic \\
\hline PF-06936308 & $\begin{array}{l}\text { A Study to Evaluate Escalating Doses of a Vaccine-Based Immunotherapy Regimen for NSCLC } \\
\text { and TNBC / Phase } 1\end{array}$ & Metastatic \\
\hline $\begin{array}{l}\text { SV-BR-1-GM } \\
\text { INCMGA00012 } \\
\text { Cyclophosphamide }\end{array}$ & $\begin{array}{l}\text { Combination Study of SV-BR-1-GM in Combination with INCMGA00012 and Epacadostat / } \\
\text { Phases } 1 \text { and } 2\end{array}$ & Metastatic \\
\hline
\end{tabular}


Table 3 (continued)

\begin{tabular}{|c|c|c|}
\hline Agents & Trial / Phase & Setting \\
\hline $\begin{array}{l}\text { Pembrolizumab } \\
\text { Flt3L } \\
\text { Poly ICLC }\end{array}$ & Vaccination with Flt3L, Radiation, and Poly-ICLC / Phases 1 and 2 & Metastatic \\
\hline $\begin{array}{l}\text { Galinpepimut-S } \\
\text { Pembrolizumab }\end{array}$ & $\begin{array}{l}\text { Galinpepimut-S in Combination with Pembrolizumab in Patients with Selected Advanced } \\
\text { Cancers / Phases } 1 \text { and } 2\end{array}$ & Metastatic \\
\hline ARG1-18,19,20 & Arginase-1 Peptide Vaccine in Patients with Metastatic Solid Tumors / Phase 1 & Metastatic \\
\hline $\begin{array}{l}\text { Durvalumab } \\
\text { Tremelimumab } \\
\text { Poly ICLC }\end{array}$ & $\begin{array}{l}\text { A Phase } 1 / 2 \text { Study of in situ Vaccination with Tremelimumab and IV Durvalumab plus } \\
\text { PolyICLC in Subjects with Advanced, Measurable, Biopsy-Accessible Cancers / Phase } 1 \text { and } 2\end{array}$ & Metastatic \\
\hline $\begin{array}{l}\text { Autologous or allogeneic } \\
\text { tumor cells }\end{array}$ & Autologous and Allogeneic Whole Cell Cancer Vaccine for Metastatic Tumors / Phases 1 and 2 & Metastatic \\
\hline $\begin{array}{l}\text { RO7198457 } \\
\text { Atezolizumab }\end{array}$ & $\begin{array}{l}\text { A Study of RO7198457 as a Single Agent and in Combination with Atezolizumab in Participants } \\
\text { with Locally Advanced or Metastatic Tumors / Phase } 1\end{array}$ & Metastatic \\
\hline
\end{tabular}

Table 4. CAR-T cell therapy trials for breast cancer in the recruitment phase

\begin{tabular}{|c|c|c|}
\hline Agents & Trial / Phase & Setting \\
\hline CAR T cells recognizing EpCAM & EpCAM CAR-T for Treatment of Nasopharyngeal Carcinoma and Breast Cancer / Phase 1 & $\begin{array}{l}\text { Adjuvant/ } \\
\text { metastatic }\end{array}$ \\
\hline $\begin{array}{l}\text { Chimeric antigen receptor T-cell } \\
\text { therapy }\end{array}$ & $\begin{array}{l}\text { HER2-CAR T Cells in Treating Patients with Recurrent Brain or Leptomeningeal Metastases / } \\
\text { Phase } 1\end{array}$ & Metastatic \\
\hline $\begin{array}{l}\text { Cyclophosphamide } \\
\text { mesothelin-targeted T cells } \\
\text { AP1903 }\end{array}$ & T-Cell Therapy for Advanced Breast Cancer / Phase 1 & Metastatic \\
\hline CEA CAR T cells & $\begin{array}{l}\text { Safety and Efficacy of CEA-Targeted CAR-T Therapy for Relapsed/Refractory CEA+ Cancer / } \\
\text { Phases } 1 \text { and } 2\end{array}$ & Metastatic \\
\hline $\begin{array}{l}\text { Cyclophosphamide } \\
\text { Fludarabine } \\
\text { Aldesleukin } \\
\text { Anti-hCD70 CAR-transduced PBL }\end{array}$ & $\begin{array}{l}\text { Administering Peripheral Blood Lymphocytes Transduced with a CD70-Binding Chimeric } \\
\text { Antigen Receptor to People with CD70 Expressing Cancers / Phases } 1 \text { and } 2\end{array}$ & Metastatic \\
\hline huMNC2-CAR44 CAR T cells & $\begin{array}{l}\text { Autologous huMNC2-CAR44 T Cells for Breast Cancer Targeting Cleaved Form of MUC1 } \\
\left(\text { MUC1*) / Phase } 1^{*}\right.\end{array}$ & Metastatic \\
\hline $\begin{array}{l}\text { C7R-GD2.CART cells } \\
\text { Cyclophosphamide } \\
\text { Fludarabine }\end{array}$ & $\begin{array}{l}\text { C7R-GD2.CART Cells for Patients with Relapsed or Refractory Neuroblastoma and Other GD2- } \\
\text { Positive Cancers (GAIL-N) / Phase } 1\end{array}$ & Metastatic \\
\hline
\end{tabular}

the treatment of metastatic triple-negative breast cancer is currently being evaluated [90]. Another adoptive cell therapy involves the use of chimeric antigen receptor (CAR) $\mathrm{T}$ cells, for which $\mathrm{T}$ cells are genetically designed to express receptors against specific targets [91]. CAR T cells are being used currently for the treatment of hemato-oncological malignancies, such as lymphoma [92]. Their application in solid tumors is being examined in experimental and clinical research [93]. Szöör et al. [93] assessed the effect of HER2-specific CAR T-cell therapy in vitro and in xenografts with trastuzumab-resistant breast cancer. They observed that HER2-specific CAR T cells induced tumor regression and proved that antibody resistance can be overcome by targeting the same epitope with CAR T cells. Promising therapeutic approaches of this type are also available for triple-negative tumors. Song et al. [94] showed that $\mathrm{T}$ cells expressing folate receptor- $\alpha$ CAR inhibited the outgrowth of triple-negative breast cancer in vitro and in xenografts. In an earlyphase clinical study, CAR T-cells specific for mesenchymal-epithelial transition factor (cMets) were injected into accessible cutaneous or lymph-node metastases in patients with metastatic breast cancer [95]. The researchers observed extensive necrosis and immune cell invasion in the excised lesions and concluded that the intratumoral injection of cMet-specific CAR T cells generated an in- 
Table 5. Anti-HER2 targeted antibody trials for breast cancer in the recruitment phase

\begin{tabular}{lll}
\hline Agent & Trial / Phase & Setting \\
\hline Margetuximab & $\begin{array}{l}\text { A Study to Evaluate the Efficacy and Safety of Margetuximab plus Chemotherapy in the Treatment } \\
\text { of Chinese Patients with HER2+ MBC / Phase 2 }\end{array}$ & Metastatic \\
\cline { 2 - 4 } & A Study of MGD013 in Patients with Unresectable or Metastatic Neoplasms / Phase 1 & Metastatic \\
\hline
\end{tabular}

flammatory response within the tumors. Table 4 provides an overview of studies examining CAR T-cell therapy for breast cancer that are currently in the recruitment phase.

\section{Anti-HER2 Targeted Antibody Therapy}

Monoclonal antibodies are identical Ig produced by clonal immune cells [96]. Although their antitumoral effect is caused by their binding ability and the inhibition of their corresponding receptor, an additional immunological pathway exists for anti-HER2-targeted monoclonal antibodies by which the adaptive and innate immune systems are activated mainly through the antibody-dependent cell-mediated cytotoxicity of natural killer cells and monocytes against tumor cells [97-100]. Margetuximab, a novel chimeric anti-HER2 IgG1 antibody [101, 102], binds to the same receptor and has anti-proliferative effects similar to those of trastuzumab, but it is intended to have a stronger effect on the immune system due to modification of the $\mathrm{Fc}$ region. This effect is mediated by the increased binding capacity of both alleles of the activating CD16A receptor and the decreased binding capacity of the negative regulator $\mathrm{CD} 32 \mathrm{~B}$ receptor [102].

The low-affinity CD16A-158F allele has been associated with a decreased clinical response to trastuzumab $[99,103]$. CD16A is an Fc receptor expressed on the surfaces of natural killer cells and macrophages that plays roles in the signal transduction antibody-dependent immune response and phagocytosis $[104,105]$. In a phase 1 study, Bang et al. [105] first investigated the toxicity profile, optimal dosing schedule, pharmacokinetics, and antitumoral activity of single-agent therapy with margetuximab $(0.1-6.0 \mathrm{mg} / \mathrm{kg}$ i.v. every 4 weeks or $10-18 \mathrm{mg} / \mathrm{kg}$ i.v. every 3 weeks) in patients with HER2-positive metastatic solid carcinomas. A tumor response was seen in 18 out of 23 (76\%) patients with breast cancer, with a tolerable safety profile [105]. In the SOPHIA study, a phase 3 clinical trial, 536 patients with metastatic breast cancer who had received therapy with pertuzumab and 1-3 lines of chemotherapy for metastatic disease were randomized to receiving combinations of margetuximab $(15 \mathrm{mg} / \mathrm{kg}$ i.v. every 21 days) or trastuzumab (6 mg/kg i.v. every 21 days) with chemotherapy (capecitabine, eribulin, gemcitabine, or vinorelbine) [106]. PFS was longer in the margetuximab arm than in the trastuzumab arm (5.8 vs.
4.9 months; $\mathrm{HR}=0.76 ; 95 \%$ CI $0.59-0.98 ; p=0.033)$. The safety profiles in the $2 \mathrm{arms}$ were comparable, with grade 3 and 4 adverse events occurring in $52.3 \%$ of the patients receiving margetuximab and $48.3 \%$ of those receiving trastuzumab. In the ITT population, the OS duration was 18.9 months in the margetuximab arm and 17.2 months in the trastuzumab arm ( $\mathrm{HR}=0.95 ; 95 \%$ CI $0.69-1.31$; $p=0.95)$. In a planned exploratory analysis conducted in patients who carried the CD16A-158F allele (which has a lower ligand-binding ability), the benefit of margetuximab for PFS was more pronounced (6.9 vs. 5.1 months; $\mathrm{HR}=0.68 ; 95 \%$ CI $0.52-0.90 ; p=0.005)$. Several ongoing clinical trials are assessing the use of margetuximab for metastatic breast cancer (Table 5).

Ertumaxomab, a trifunctional bispecific antibody currently under clinical testing, targets HER2, CD3, and the Fc $\gamma$ receptors I, IIa, and III and forms a tri-cell complex of tumor, T, and accessory cells [107, 108]. In a phase 1 study, Kiewe et al. [109] found that ertumaxomab elicited a clinical response in 5 out of 15 patients with metastatic breast cancer, as well as a strong $\mathrm{T}$ cell-associated immune response, with an acceptable number of drug-related adverse events.

\section{Cytokine-Activated Mediation Therapy}

Another treatment strategy is based on the assumption that monoclonal antibody therapy activates a signal that stimulates the release of type 1 IFN and INF- $\gamma$-producing CD8+ T cells $[97,110]$. Continuing this thought, concepts are being developed and early studies are being conducted to examine the combination of IFN- $\gamma$ and anti-HER2 antibodies [111]. Zhang et al. [111] produced an antiHER2 single-chain variable fragment-IFN- $\gamma$ fusion protein that showed activity superior to that of anti-HER2 antibodies in xenografts and was even effective on tumors with anti-HER2 resistance. In a phase 1 study, Han et al. [112] assessed the effect of IFN- $\gamma$ administered weekly in combination with paclitaxel, trastuzumab, and pertuzumab in patients with HER2-positive breast cancer. The 9 enrolled patients tolerated the therapy well, but oncological outcomes from that study remain to be published [112]. 
Table 6. Oncolytic virus therapy for breast cancer in the recruitment phase

\begin{tabular}{|c|c|c|}
\hline Agents & Trial / Phase & Setting \\
\hline $\begin{array}{l}\text { Pelareorep, letrozole, } \\
\text { atezolizumab, trastuzumab }\end{array}$ & A Window-of-Opportunity Study of Pelareorep in Early Breast Cancer / Phase 1 & Neoadjuvant \\
\hline $\begin{array}{l}\text { Ipilimumab, nivolumab, } \\
\text { talimogene, laherparepvec }\end{array}$ & $\begin{array}{l}\text { Ipilimumab, Nivolumab, and Talimogene Laherparepvec before Surgery in Treating Participants } \\
\text { with Localized, Triple-Negative or Estrogen Receptor-Positive, HER2-Negative Breast Cancer- } \\
\text { Deleted / Phase } 1\end{array}$ & Neoadjuvant \\
\hline Paclitaxel, pelareorep, avelumab & $\begin{array}{l}\text { A Study to Assess Overall Response Rate by Inducing an Inflammatory Phenotype in Metastatic } \\
\text { BReast cAnCEr with the Oncolytic Reovirus PeLareorEp in CombinaTion with Anti-PD-L1 } \\
\text { Avelumab and Paclitaxel - BRACELET-1 Study / Phase } 2\end{array}$ & Metastatic \\
\hline $\begin{array}{l}\text { ADV/HSV-tk, valacyclovir, } \\
\text { radiation: SBRT, pembrolizumab }\end{array}$ & $\begin{array}{l}\text { SBRT and Oncolytic Virus Therapy before Pembrolizumab for Metastatic TNBC and NSCLC / } \\
\text { Phase } 2\end{array}$ & Metastatic \\
\hline PVSRIPO & Examining Bioactivity of PVSRIPO in Invasive Breast Cancer / Phase 1 & Metastatic \\
\hline Pelareorep, retifanlimab & $\begin{array}{l}\text { INCMGA00012 and Pelareorep for the Treatment of Metastatic Triple-Negative Breast Cancer, } \\
\text { IRENE Study / Phase } 2\end{array}$ & Metastatic \\
\hline $\begin{array}{l}\text { Cyclophosphamide and JX-594 } \\
\text { dose escalation, cyclophosphamide } \\
\text { and JX-594, cyclophosphamide }\end{array}$ & $\begin{array}{l}\text { A Study of Metronomic CP and JX-594 in Patients with Advanced Breast Cancer and Advanced } \\
\text { Soft-Tissue Sarcoma (METROmaJX) / Phases } 1 \text { and } 2\end{array}$ & Metastatic \\
\hline TBio-6517, pembrolizumab & $\begin{array}{l}\text { Study of TBio-6517, Given Intratumorally, Alone or in Combination with Pembrolizumab, in Solid } \\
\text { Tumors / Phases } 1 \text { and } 2\end{array}$ & Metastatic \\
\hline ONCR-177, pembrolizumab & $\begin{array}{l}\text { Study of ONCR-177 Alone and in Combination with PD-1 Blockade in Adult Subjects with } \\
\text { Advanced and/or Refractory Cutaneous, Subcutaneous or Metastatic Nodal Solid Tumors / Phase } 1\end{array}$ & Metastatic \\
\hline
\end{tabular}

\section{Oncolytic Virus Immunotherapy}

Oncolytic viruses (OV) are being used in a novel approach to immunotherapy, as they can induce cancer cell death, and to enhance the immune response to cancer [113]. They replicate in cancer cells and induce cell death without harming physiologic cells. Infection of the cancer cell can be achieved via membrane fusion or binding to surface receptors $[114,115]$. Various mechanisms underlie the antitumoral activity of different OV. The induction of lysis of cancer cells and cytotoxic proteins against them, insertion of therapeutic genes into the viral genome, sensitization of tumor cells to other treatments, enhancement of tumor apoptotic activity, and amplification of the antitumoral immune response are possible mechanisms $[114,116]$. The FDA approved talimogene laherparepvec, the first herpes simplex OV, for the treatment of metastatic melanoma in 2015. OV for breast cancer are being tested in preclinical models and very earlystage clinical trials. Because of their immune-stimulating effects, $\mathrm{OV}$ are being assessed as monotherapy and in combination with other immunotherapeutic agents [117]. A phase 1 dose-escalation study assessed the clinical efficacy and safety of single and recurrent intratumoral doses of the herpes simplex OV HF10 in 6 patients with recurrent breast cancer; the researchers reported that the agent was safe and well tolerated, with therapeutic potential $[118,119]$. In a similar phase 1 clinical trial, the antitumoral activity of combination therapy with docetaxel $\left(75 \mathrm{mg} / \mathrm{m}^{2}\right.$ i.v. every 3 weeks) and escalating doses of reo- virus type 3 Dearing (i.v., median tissue culture infectious dose up to $3 \times 10^{10}$ on days $1-5$ every 3 weeks) was assessed in 25 oncological patients; 1 patient had metastatic breast cancer and showed a complete response to treatment $[120,121]$. In vivo studies have investigated the effects of OV as monotherapy, in combination with chemotherapy, and as sensitizers for ICI therapy in the neoadjuvant setting on triple-negative breast cancer, and they have shown durable response rates $[122,123]$. Thus, data on OV to date have been generated mainly in preclinical models; a few clinical trials have been conducted, albeit with small samples of patients with various types of cancer. Additional studies are currently underway and will better characterize the clinical effectiveness of this approach (Table 6).

\section{Conclusion}

Immunotherapy is a rapidly emerging field in breast cancer, as evidenced by the plethora of preclinical and clinical concepts and ongoing trials. Initial studies established the role of immunotherapeutic agents as checkpoint inhibitors in the metastatic setting. Questions that remain to be answered include which chemotherapeutic backbone the optimal partner for combination therapy is, which combinations with other immune-oncologic substances are effective, and which timing of application is optimal. As immunogenic factors, such as PD-L1 and TIL 
expression, decrease over the course of disease, an important aspect of immunotherapy will be its effectiveness for early-stage breast cancer. Another important aspect will be the identification of suitable biomarkers to identify patients who will benefit from certain treatment approaches. Understanding of the tumor microenvironment, the roles of the innate and adaptive immune systems in the development and progression of breast cancer, and factors that account for responses to immunotherapeutic agents is necessary to enable immunotherapy to come of age fully in breast cancer treatment.

\section{Conflict of Interest Statement}

The authors declare the following conflicts of interests. JCR has received travel grants from Medac $\mathrm{GmbH}$ (Wedel, Germany), Gedeon Richter (Budapest, Hungary), Celgene (Summit, NJ, USA), Daiichi Sankyo (Tokyo, Japan), and Pfizer (New York City, NY, USA) and has been an honorary speaker for Pfizer. L.S. has received travel grants from Medac $\mathrm{GmbH}$ (Wedel, Germany) and Celgene (Summit, USA) outside the scope of this work. E.-F.S. is receiving: grants from the University of Saarland, Storz, and Erbe; personal fees and other compensation from Roche (Basel, Switzerland), Pfizer (New York City, NY, USA), Celgene (Summit USA), Amgen (Thousand Oaks, CA, USA), and Astra Zeneca (Cambridge, UK); and other fees from Esai (Tokyo, Japan), Ethicon (Somerville, NJ, USA), Johnson \& Johnson (New Brunswick, NJ, USA), Novartis (Basel, Switzerland), Tesaro (Waltham, MA, USA), Teva (Petach Tikwa, Israel), Medac GmbH (Wedel, Germany), MSD (Kenilworth, NJ, USA), Vifor (Sankt Gallen, Switzerland), Gedeon Richter (Budapest, Hungary), Takeda (Tokyo, Japan), and AGE (Buchholz, Germany).

\section{Funding Sources}

None.

\section{Author Contributions}

J.C.R. and M.P.R. were responsible for the conception and design of this study, interpretation of data, and drafting of this paper. L.S., C.M., and A.C.K. contributed substantially to the drafting and editing of this work. E.F.-S. was involved in the conception of this study and critical revision of this paper. All of the authors reviewed this work and contributed to the final version submitted.

\section{References}

1 Bayraktar S, Batoo S, Okuno S, Glück S. Immunotherapy in breast cancer. J Carcinog. 2019 May; 18(1):2.

2 Schreiber RD, Old LJ, Smyth MJ. Cancer immunoediting: integrating immunity's roles in cancer suppression and promotion. Science. 2011 Mar;331(6024):1565-70.

3 Mittal D, Gubin MM, Schreiber RD, Smyth MJ. New insights into cancer immunoediting and its three component phases: elimination, equilibrium and escape. Curr Opin Immunol. 2014 Apr;27:16-25.

4 Gatti-Mays ME, Balko JM, Gameiro SR, Bear HD, Prabhakaran S, Fukui J, et al. If we build it they will come: targeting the immune response to breast cancer. NPJ Breast Cancer. 2019 Oct 29;5:37.

5 Beckers RK, Selinger CI, Vilain R, Madore J, Wilmott JS, Harvey K, et al. Programmed death ligand 1 expression in triple-negative breast cancer is associated with tumour-infiltrating lymphocytes and improved outcome. Histopathology. 2016 Jul;69(1):25-34.

6 Thorsson V, Gibbs DL, Brown SD, Wolf D, Bortone DS, Ou Yang TH, et al.; Cancer Genome Atlas Research Network. The immune landscape of cancer. Immunity. 2018 Apr; 48(4):812-830.e14.

7 Force J, Leal JH, McArthur HL. Checkpoint blockade strategies in the treatment of breast cancer: where we are and where we are heading. Curr Treat Options Oncol. 2019 Mar 28; 20(4):35.

8 McArthur HL, Page DB. Immunotherapy for the treatment of breast cancer: checkpoint blockade, cancer vaccines, and future directions in combination immunotherapy. Clin Adv Hematol Oncol. 2016 Nov;14(11):92233.
9 Adams S, Gatti-Mays ME, Kalinsky K, Korde LA, Sharon E, Amiri-Kordestani L, et al. Current landscape of immunotherapy in breast cancer: A review. JAMA Oncol. doi: 10.1001/ jamaoncol.2018.7147.

10 Mittendorf EA, Philips AV, Meric-Berns$\operatorname{tam}$ F, Qiao N, Wu Y, Harrington S, et al. PD-L1 expression in triple-negative breast cancer. Cancer Immunol Res. 2014 Apr; 2(4):361-70.

11 Emens LA, Cruz C, Eder JP, Braiteh F, Chung C, Tolaney SM, et al. Long-term clinical outcomes and biomarker analyses of atezolizumab therapy for patients with metastatic triplenegative breast cancer: a phase 1 study. JAMA Oncol. 2019 Jan;5(1):74-82.

12 Nanda R, Chow LQ, Dees EC, Berger R, Gupta $S, G e v a$ R, et al. Pembrolizumab in patients with advanced triple-negative breast cancer: phase Ib keynote-012 study. J Clin Oncol. 2016 Jul;34(21):2460-7

13 Dirix LY, Takacs I, Jerusalem G, Nikolinakos $\mathrm{P}$, Arkenau HT, Forero-Torres A, et al. Avelumab, an anti-PD-L1 antibody, in patients with locally advanced or metastatic breast cancer: a phase 1b JAVELIN Solid Tumor study. Breast Cancer Res Treat. 2018 Feb; 167(3):671-86.

14 Adams S, Loi S, Toppmeyer D, Cescon DW, De Laurentiis M, Nanda R, et al. Pembrolizumab monotherapy for previously untreated, PD-L1-positive, metastatic triple-negative breast cancer: cohort B of the phase II KEYNOTE-086 study. Ann Oncol. 2019 Mar; 30(3):405-11.
15 Winer EP, Dang T, Karantza V, Su SC. KEYNOTE-119: A randomized phase III study of single-agent pembrolizumab (MK-3475) vs single-agent chemotherapy per physician's choice for metastatic triple-negative breast cancer (mTNBC). J Clin Oncol. 2016 May; 34:TPS1102.

16 Bracci L, Schiavoni G, Sistigu A, Belardelli F. Immune-based mechanisms of cytotoxic chemotherapy: Implications for the design of novel and rationale-based combined treatments against cancer. Cell Death Differ. 2014 Jan;21(1):15-25.

17 Schmid P, Rugo HS, Adams S, Schneeweiss A, Barrios $\mathrm{CH}$, Iwata $\mathrm{H}$, et al.; IMpassion130 Investigators. Atezolizumab plus nab-paclitaxel as first-line treatment for unresectable, locally advanced or metastatic triple-negative breast cancer (IMpassion130): updated efficacy results from a randomised, double-blind, placebo-controlled, phase 3 trial. Lancet Oncol. 2020 Jan;21(1):44-59.

18 Cortés J, Guo Z, Karantza V, Aktan G. KEYNOTE-355: Randomized, double-blind, phase III study of pembrolizumab (pembro) + chemotherapy (chemo) vs placebo $(\mathrm{PBO})+$ chemo for previously untreated, locally recurrent, inoperable or metastatic triple-negative breast cancer (mTNBC). J Clin Oncol. 2018 Feb;36:TPS18.

19 Cortés J, André F, Gonçalves A, Kümmel S, Martín M, Schmid P, et al. IMpassion132 phase III trial: atezolizumab and chemotherapy in early relapsing metastatic triple-negative breast cancer. Future Oncol. 2019 Jun; 15(17):1951-61. 
20 Merck \& Co. Inc. Merck's KEYTRUDA ${ }^{\circledR}$ (pembrolizumab) in combination with chemotherapy met primary endpoint of progressionfree survival (PFS) as first-line treatment for metastatic triple-negative breast cancer ( $\mathrm{mT}$ NBC) [Internet]. [cited 2020 May 12]. Available from: https://investors.merck.com/news/ press-release-details/2020/Mercks-KEYTRUDA-pembrolizumab-in-Combination-withChemotherapy-Met-Primary-Endpoint-ofProgression-Free-Survival-PFS-as-First-LineTreatment-for-Metastatic-Triple-NegativeBreast-Cancer-mTNBC/default.aspx.

21 Tolaney S, Kalinsky K, Kaklamani V, Savulsky C, Olivo M, Aktan G, et al. Abstract PD6-13. Phase $1 \mathrm{~b} / 2$ study to evaluate eribulin mesylate in combination with pembrolizumab in patients with metastatic triple-negative breast cancer. Cancer Res. 2018;78(4 suppl):PD613-PD6.

22 Voorwerk L, Slagter M, Horlings HM, Sikorska K, van de Vijver KK, de Maaker M, et al. Immune induction strategies in metastatic triple-negative breast cancer to enhance the sensitivity to PD-1 blockade: the TONIC trial. Nat Med. 2019 Jun;25(6):920-8.

23 Dalenc F, Garberis I, Filleron T, Lusque A, Bachelot T, Arnedos M, et al. Abstract GS302: Durvalumab compared to maintenance chemotherapy in patients with metastatic breast cancer: Results from phase II randomized trial SAFIR02-IMMUNO. San Antonio Breast Cancer Symposium. 2019 Dec 10-14; San Antonio, TX, USA.

24 Ogiya R, Niikura N, Kumaki N, Bianchini G, Kitano S, Iwamoto T, et al. Comparison of tumor-infiltrating lymphocytes between primary and metastatic tumors in breast cancer patients. Cancer Sci. 2016 Dec;107(12):1730-5.

25 Manson QF, Schrijver WA, Ter Hoeve ND, Moelans CB, van Diest PJ. Frequent discordance in PD-1 and PD-L1 expression between primary breast tumors and their matched distant metastases. Clin Exp Metastasis. 2019 Feb;36(1):29-37.

26 Schmid P, Salgado R, Park YH, MuñozCouselo E, Kim SB, Sohn J, et al. Pembrolizumab plus chemotherapy as neoadjuvant treatment of high-risk, early-stage triple-negative breast cancer: results from the phase $1 \mathrm{~b}$ open-label, multicohort KEYNOTE-173 study. Ann Oncol. 2020 May;31(5):569-81.

27 Schmid P, Cortes J, Pusztai L, McArthur H, Kümmel S, Bergh J, et al.; KEYNOTE-522 Investigators. Pembrolizumab for Early TripleNegative Breast Cancer. N Engl J Med. 2020 Feb;382(9):810-21.

28 Gianni L, Huang CS, Egle D, Bermejo B, Zamagni C, Thill M, et al. Abstract GS3-04: Pathologic complete response (pCR) to neoadjuvant treatment with or without atezolizumab in triple negative, early high-risk and locally advanced breast cancer. NeoTRIPaP DL1 Michelangelo randomized study. Cancer Res. 2020. doi: 10.1158/1538-7445.SABCS19GS3-04.

29 Loibl S, Untch M, Burchardi N, Huober J, Sinn BV, Blohmer JU, et al. A randomised phase II study investigating durvalumab in addition to an anthracycline taxane-based neoadjuvant therapy in early triple-negative breast cancer: clinical results and biomarker analysis of GeparNuevo study. Ann Oncol. 2019 Aug;30(8):1279-88.

30 Zhang C, Liu Y. Targeting NK cell checkpoint receptors or molecules for cancer immunotherapy. Front Immunol. 2020;11:1295.

31 Sansom DM, Walker LS. The role of CD28 and cytotoxic T-lymphocyte antigen-4 (CTLA-4) in regulatory T-cell biology. Immunol Rev. 2006 Aug;212:131-48.

32 Rudd CE, Taylor A, Schneider H. CD28 and CTLA-4 coreceptor expression and signal transduction. Immunol Rev. 2009 May; 229(1):12-26

33 Vonderheide RH, LoRusso PM, Khalil M, Gartner EM, Khaira D, Soulieres D, et al. Tremelimumab in combination with exemestane in patients with advanced breast cancer and treatment-associated modulation of inducible costimulator expression on patient T cells. Clin Cancer Res. 2010 Jul;16(13):3485-94.

34 McArthur HL, Diab A, Page DB, Yuan J, Solomon SB, Sacchini V, et al. A pilot study of preoperative single-dose ipilimumab and/or cryoablation in women with early-stage breast cancer with comprehensive immune profiling. Clin Cancer Res. 2016 Dec;22(23): 5729-37.

35 Sistigu A, Yamazaki T, Vacchelli E, Chaba K, Enot DP, Adam J, et al. Cancer cell-autonomous contribution of type I interferon signaling to the efficacy of chemotherapy. Nat Med. 2014 Nov;20(11):1301-9.

36 Javeed A, Ashraf M, Riaz A, Ghafoor A, Afzal S, Mukhtar MM. Paclitaxel and immune system. Eur J Pharm Sci. 2009 Nov;38(4):283-90.

37 Vincent J, Mignot G, Chalmin F, Ladoire S, Bruchard M, Chevriaux A, et al. 5-Fluorouracil selectively kills tumor-associated myeloidderived suppressor cells resulting in enhanced T cell-dependent antitumor immunity. Cancer Res. 2010 Apr;70(8):3052-61.

38 Ramakrishnan R, Assudani D, Nagaraj S, Hunter T, Cho H. Il, Antonia S, et al. Chemotherapy enhances tumor cell susceptibility to CTL-mediated killing during cancer immunotherapy in mice. J Clin Invest. 2010 Apr; 120(4):1111-24.

39 Fine JH, Chen P, Mesci A, Allan DS, Gasser S, Raulet $\mathrm{DH}$, et al. Chemotherapy-induced genotoxic stress promotes sensitivity to natural killer cell cytotoxicity by enabling missingself recognition. Cancer Res. 2010 Sep;70(18): 7102-13.

40 Esteva FJ, Wang J, Lin F, Mejia JA, Yan K, Altundag $\mathrm{K}$, et al. CD40 signaling predicts response to preoperative trastuzumab and concomitant paclitaxel followed by 5 -fluorouracil, epirubicin, and cyclophosphamide in HER-2-overexpressing breast cancer. Breast Cancer Res. 2007 Dec;9(6):R87.

41 Esteva FJ, Yu D, Hung MC, Hortobagyi GN. Molecular predictors of response to trastuzumab and lapatinib in breast cancer. Nat Rev Clin Oncol. 2010 Feb;7(2):98-107.

42 Loi S, Giobbie-Hurder A, Gombos A, Bachelot T, Hui R, Curigliano G, et al.; International Breast Cancer Study Group; Breast International Group. Pembrolizumab plus trastuzumab in trastuzumab-resistant, advanced, HER2-positive breast cancer (PANACEA): a single-arm, multicentre, phase $1 \mathrm{~b}-2$ trial. Lancet Oncol. 2019 Mar;20(3):371-82.
43 Chia S, Bedard PL, Hilton J, Amir E, Gelmon $\mathrm{K}$, Goodwin R, et al. A phase Ib trial of durvalumab in combination with trastuzumab in HER2-positive metastatic breast cancer (CCTG IND.229). Oncologist. 2019 Nov; 24(11):1439-45.

44 Emens L, Esteva F, Beresford M, Saura C, De Laurentiis M, Kim SB, et al. Abstract PD3-01: Results from KATE2, a randomized phase 2 study of atezolizumab (atezo)+trastuzumab emtansine (T-DM1) vs placebo (pbo)+T-DM1 in previously treated HER2+ advanced breast cancer (BC). Cancer Res. 2019;79:PD3-01.

45 Jiao S, Xia W, Yamaguchi H, Wei Y, Chen $\mathrm{MK}, \mathrm{Hsu} \mathrm{JM}$, et al. PARP inhibitor upregulates PD-L1 expression and enhances cancerassociated immunosuppression. Clin Cancer Res. 2017 Jul;23(14):3711-20.

46 Esteva FJ, Hubbard-Lucey VM, Tang J, Pusztai L. Immunotherapy and targeted therapy combinations in metastatic breast cancer. Lancet Oncol. 2019 Mar;20(3):e175-86.

47 Ding L, Kim HJ, Wang Q, Kearns M, Jiang T, Ohlson CE, et al. PARP inhibition elicits STING-dependent antitumor immunity in Brcal-deficient ovarian cancer. Cell Rep. 2018 Dec;25(11):2972-80.e5.

48 Shen J, Zhao W, Ju Z, Wang L, Peng Y, Labrie $\mathrm{M}$, et al. PARPI triggers the STING-dependent immune response and enhances the therapeutic efficacy of immune checkpoint blockade independent of BRCANEss. Cancer Res. 2019 Jan;79(2):311-9.

49 Bang YJ, Kaufman B, Geva R, Stemmer SM, Hong SH, Lee JS, et al. An open-label, phase II basket study of olaparib and durvalumab (MEDIOLA): results in patients with relapsed gastric cancer. J Clin Oncol. 2019 Feb;37(4 suppl): 140 .

50 Vinayak S, Tolaney SM, Schwartzberg LS Mita MM, McCann GA, Tan AR, et al. TOPACIO/Keynote-162: Niraparib + pembrolizumab in patients (pts) with metastatic triple-negative breast cancer (TNBC), a phase 2 trial. J Clin Oncol. 2018 May;36(15 suppl):1011.

51 Goetz MP, Toi M, Campone M, Sohn J, Paluch-Shimon S, Huober J, et al. MONARCH 3: abemaciclib as initial therapy for advanced breast cancer. J Clin Oncol. 2017 Nov; 35(32):3638-46.

52 Iwata H, Im SA, Masuda N, Im YH, Inoue K, Rai Y, et al. PALOMA-3: Phase III trial of fulvestrant with or without palbociclib in premenopausal and postmenopausal women with hormone receptor-positive, human epidermal growth factor receptor 2-negative metastatic breast cancer that progressed on prior endocrine therapy - safety and efficacy in Asian patients. J Glob Oncol. 2017 Aug; 3(4):289-303

53 Slamon DJ, Neven P, Chia S, Fasching PA, De Laurentiis M, Im SA, et al. Phase III randomized study of ribociclib and fulvestrant in hormone receptor-positive, human epidermal growth factor receptor 2-negative advanced breast cancer: MONALEESA-3. J Clin Oncol. 2018 Aug;36(24):2465-72.

54 Goel S, DeCristo MJ, Watt AC, BrinJones H, Sceneay J, Li BB, et al. CDK4/6 inhibition triggers anti-tumour immunity. Nature. 2017 Aug;548(7668):471-5. 
55 Deng J, Wang ES, Jenkins RW, Li S, Dries R, Yates $\mathrm{K}$, et al. CDK4/6 inhibition augments antitumor immunity by enhancing T-cell activation. Cancer Discov. 2018 Feb;8(2):21633.

56 Guan X, LaPak KM, Hennessey RC, Yu CY, Shakya R, Zhang J, et al. Stromal senescence by prolonged CDK4/6 inhibition potentiates tumor growth. Mol Cancer Res. 2017 Mar; 15(3):237-49.

57 Tolaney SM, Kabos P, Dickler MN, Gianni L, Jansen V, Lu Y, et al. Updated efficacy, safety, \& PD-L1 status of patients with $\mathrm{HR}+$, HER2metastatic breast cancer administered abemaciclib plus pembrolizumab. J Clin Oncol. 2018 May;36:1059.

58 Dickler MN, Tolaney SM, Rugo HS, Cortes J Dieras V, Patt D, et al. MONARCH 1, a phase II study of abemaciclib, a CDK4 and CDK6 inhibitor, as a single agent, $\mathrm{n}$ patients with refractory HR+/HER2- metastatic breast cancer. Clin Cancer Res. 2017;23(17):5218-24.

59 Wolchok JD, Kluger H, Callahan MK, Postow MA, Rizvi NA, Lesokhin AM, et al. Nivolumab plus ipilimumab in advanced melanoma. N Engl J Med. 2013 Jul;369(2):122-33.

60 Larkin J, Chiarion-Sileni V, Gonzalez R, Grob JJ, Cowey CL, Lao CD, et al. Combined nivolumab and ipilimumab or monotherapy in untreated melanoma. N Engl J Med. 2015 Jul;373(1):23-34.

61 Santa-Maria CA, Kato T, Park JH, Kiyotani K, Rademaker A, Shah AN, et al. A pilot study of durvalumab and tremelimumab and immunogenomic dynamics in metastatic breast cancer. Oncotarget. 2018 Apr;9(27):1898596.

62 Figdor CG, De Vries IJ, Lesterhuis WJ, Melief CJ. Dendritic cell immunotherapy: Mapping the way. Nat Med. 2004 May;10(5):475-80.

63 Segal NH, Parsons DW, Peggs KS, Velculescu V, Kinzler KW, Vogelstein B, et al. Epitope landscape in breast and colorectal cancer. Cancer Res. 2008 Feb;68(3):889-92.

64 Chen H, Zhang W, Zhu G, Xie J, Chen X. Rethinking cancer nanotheranostics. Nat Rev Mater. 2017;2:17024.

65 Hollingsworth RE, Jansen K. Turning the corner on therapeutic cancer vaccines. NPJ Vaccines. 2019 Feb 8;4:7.

66 Castle IC, Kreiter S, Diekmann J, Löwer M, van de Roemer N, de Graaf J, et al. Exploiting the mutanome for tumor vaccination. Cancer Res. 2012 Mar;72(5):1081-91.

67 Kreiter S, Vormehr M, van de Roemer N, Diken M, Löwer M, Diekmann J, et al. Mutant MHC class II epitopes drive therapeutic immune responses to cancer. Nature. 2015 Apr; 520(7549):692-6

68 Pedersen SR, Sørensen MR, Buus S, Christensen JP, Thomsen AR. Comparison of vaccine-induced effector CD8 T cell responses directed against self- and non-self-tumor antigens: implications for cancer immunotherapy. J Immunol. 2013 Oct;191(7):3955-67.

69 Overwijk WW. Cancer vaccines in the era of checkpoint blockade: the magic is in the adjuvant. Curr Opin Immunol. 2017 Aug;47:103-9.

70 Chrisikos TT, Zhou Y, Li HS, Babcock RL, Wan X, Patel B, et al. STAT3 inhibits CD103+ cDC1 vaccine efficacy in murine breast cancer. Cancers (Basel). 2020 Jan;12(1):E128.
71 Chablani L, Tawde SA, Akalkotkar A, D'Souza MJ. Evaluation of a particulate breast cancer vaccine delivered via skin. AAPS J. 2019 Jan; 21(2):12.

72 Sahin U, Derhovanessian E, Miller M, Kloke BP, Simon P, Löwer M, et al. Personalized RNA mutanome vaccines mobilize poly-specific therapeutic immunity against cancer. Nature. 2017 Jul;547(7662):222-6.

73 Teixeira L, Medioni J, Garibal J, Adotevi O, Doucet L, Durey MD, et al. A first-in-human phase I study of INVAC-1, an optimized human telomerase DNA vaccine in patients with advanced solid tumors. Clin Cancer Res. 2020 Feb;26(3):588-97.

74 Mittendorf EA, Clifton GT, Holmes JP, Clive KS, Patil R, Benavides LC, et al. Clinical trial results of the HER-2/neu (E75) vaccine to prevent breast cancer recurrence in high-risk patients: from US Military Cancer Institute Clinical Trials Group Study I-01 and I-02. Cancer. 2012 May;118(10):2594-602.

75 Peoples GE, Holmes JP, Hueman MT, Mittendorf EA, Amin A, Khoo S, et al. Combined clinical trial results of a HER2/neu (E75) vaccine for the prevention of recurrence in highrisk breast cancer patients: U.S. Military Cancer Institute Clinical Trials Group Study I-01 and I-02. Clin Cancer Res. 2008 Feb;14(3): 797-803

76 Benavides LC, Gates JD, Carmichael MG, Patil R, Holmes JP, Hueman MT, et al. The impact of HER2/neu expression level on response to the E75 vaccine: from U.S. Military Cancer Institute Clinical Trials Group Study I-01 and I-02. Clin Cancer Res. 2009 Apr; 15(8):2895-904.

77 Mittendorf EA, Lu B, Melisko M, Price Hiller J, Bondarenko I, Brunt AM, et al. Efficacy and safety analysis of nelipepimut-S vaccine to prevent breast cancer recurrence: A randomized, multicenter, phase III clinical trial. Clin Cancer Res. 2019 Jul;25(14):4248-54.

78 Miles DW, Happerfield LC, Smith P, Gillibrand R, Bobrow LG, Gregory WM, et al. Expression of sialyl-Tn predicts the effect of adjuvant chemotherapy in node-positive breast cancer. Br J Cancer. 1994 Dec;70(6):1272-5.

79 Holmberg LA, Sandmaier BM. Vaccination with Theratope (STn-KLH) as treatment for breast cancer. Expert Rev Vaccines. 2004 Dec; 3(6):655-63.

80 Miles DW, Linehan J, Smith P, Filipe I. Expression of sialyl-Tn in gastric cancer: correlation with known prognostic factors. $\mathrm{Br} \mathrm{J}$ Cancer. 1995 May;71(5):1074-6.

81 The prognostic significance of sialyl-Tn antigen in women treated with breast carcinoma treated with adjuvant chemotherapy. Cancer. 1997 Dec 15;80(12):2240-9.

82 Kobayashi H, Terao T, Kawashima Y. Serum sialyl Tn as an independent predictor of poor prognosis in patients with epithelial ovarian cancer. J Clin Oncol. 1992 Jan;10(1):95-101.

83 Longenecker BM, Reddish M, Koganty R, MacLean GD. Immune responses of mice and human breast cancer patients following immunization with synthetic sialyl-Tn conjugated to KLH plus detox adjuvant. Ann NY Acad Sci. 1993 Aug;690(1):276-91.
84 Miles D, Roché H, Martin M, Perren TJ, Cameron DA, Glaspy J, et al.; Theratope ${ }^{\circledR}$ Study Group. Phase III multicenter clinical trial of the sialyl-TN (STn)-keyhole limpet hemocyanin (KLH) vaccine for metastatic breast cancer. Oncologist. 2011;16(8):1092-100.

85 Wei X, Xu H, Kufe D. MUC1 oncoprotein stabilizes and activates estrogen receptor $\alpha$. Mol Cell. 2006 Jan;21(2):295-305.

86 Ibrahim NK, Murray JL, Zhou D, Mittendorf EA, Sample D, Tautchin M, et al. Survival advantage in patients with metastatic breast cancer receiving endocrine therapy plus sialyl Tn-KLH vaccine: post hoc analysis of a large randomized trial. J Cancer. 2013 Aug;4(7): 577-84.

87 Rosenberg SA, Restifo NP. Adoptive cell transfer as personalized immunotherapy for human cancer. Science. 2015 Apr 3;348(6230): 62-8.

88 Kim I, Sanchez K, McArthur HL, Page D. Immunotherapy in triple-negative breast cancer: present and future. Vol. 11, Curr Breast Cancer Rep. 2019 Nov; 11:259-71.

89 Zacharakis N, Chinnasamy H, Black M, Xu H, $\mathrm{Lu} \mathrm{YC}$, Zheng Z, et al. Immune recognition of somatic mutations leading to complete durable regression in metastatic breast cancer. Nat Med. 2018 Jun;24(6):724-30.

90 Assadipour Y, Zacharakis N, Crystal JS, Prickett TD, Gartner JJ, Somerville RP, et al. Characterization of an immunogenic mutation in a patient with metastatic triple-negative breast cancer. Clin Cancer Res. 2017 Aug 23(15):4347-53.

91 June CH, O'Connor RS, Kawalekar OU, Ghassemi S, Milone MC. CAR T cell immunotherapy for human cancer. Science. 2018 Mar 23;359(6382):1361-5.

92 El-Galaly TC, Cheah CY, Kristensen D, Hutchison A, Hay K, Callréus T, et al. Potentials, challenges and future of chimeric antigen receptor T-cell therapy in non-Hodgkin lymphomas. Acta Oncol. 2020 Jul;59(7):766-74.

93 Szöör Á, Tóth G, Zsebik B, Szabó V, Eshhar Z Abken H, et al. Trastuzumab derived HER2specific CARs for the treatment of trastuzumab-resistant breast cancer: CAR T cells penetrate and eradicate tumors that are not accessible to antibodies. Cancer Lett. 2020 Aug; 484:1-8.

94 Song DG, Ye Q, Poussin M, Chacon JA, Figini M, Powell DJ Jr. Effective adoptive immunotherapy of triple-negative breast cancer by folate receptor-alpha redirected CAR T cells is influenced by surface antigen expression level. J Hematol Oncol. 2016 Jul;9(1):56.

95 Tchou J, Zhao Y, Levine BL, Zhang PJ, Davis MM, Melenhorst JJ, et al. Safety and efficacy of intratumoral injections of chimeric antigen receptor (CAR) $\mathrm{T}$ cells in metastatic breast cancer. Cancer Immunol Res. 2017 Dec;5(12) 1152-61.

96 Tansey EM, Catterall PP. Monoclonal antibodies: a witness seminar in contemporary medical history. Med Hist. 1994 Jul;38(3): 322-7.

97 Costa RL, Czerniecki BJ. Clinical development of immunotherapies for HER2+ breast cancer: a review of HER2-directed monoclonal antibodies and beyond. NPJ Breast Cancer. 2020 Mar 12;6:10. 
98 Shields RL, Namenuk AK, Hong K, Meng YG, Rae J, Briggs J, et al. High resolution mapping of the binding site on human IgG1 for Fc $\gamma$ RI, Fc $\gamma$ RII, Fc $\gamma$ RIII, and FcRn and design of IgG1 variants with improved binding to the Fc $\gamma$ R. J Biol Chem. 2001 Mar; 276(9):6591-604.

99 Musolino A, Naldi N, Bortesi B, Pezzuolo D, Capelletti M, Missale G, et al. Immunoglobulin $\mathrm{G}$ fragment $\mathrm{C}$ receptor polymorphisms and clinical efficacy of trastuzumab-based therapy in patients with HER-2/neu-positive metastatic breast cancer. J Clin Oncol. 2008 Apr;26(11):1789-96.

100 Park S, Jiang Z, Mortenson ED, Deng L, Radkevich-Brown O, Yang X, et al. The therapeutic effect of anti-HER2/neu antibody depends on both innate and adaptive immunity. Cancer Cell. 2010 Aug;18(2):160-70.

101 Kaplon H, Muralidharan M, Schneider Z, Reichert JM. Antibodies to watch in 2020. MAbs. 2020 Jan-Dec;12(1):1703531.

102 Nordstrom JL, Gorlatov S, Zhang W, Yang Y, Huang L, Burke S, et al. Anti-tumor activity and toxicokinetics analysis of MGAH22, an anti-HER2 monoclonal antibody with enhanced $\mathrm{F} c \gamma$ receptor binding properties. Breast Cancer Res. 2011;13(6):R123.

103 Gavin PG, Song N, Kim SR, Lipchik C, Johnson NL, Bandos $\mathrm{H}$, et al. Association of polymorphisms in FCGR2A and FCGR3A with degree of trastuzumab benefit in the adjuvant treatment of ERBB2/HER2-positive breast cancer analysis of the NSABP B-31 trial. JAMA Oncol. 2017 Mar;3(3):335-41.

104 Li XY, Wu L, Li SW, Zhou WB, Wang MY, Zuo GQ, et al. Effect of CD16a, the surface receptor of Kupffer cells, on the growth of hepatocellular carcinoma cells. Int $\mathrm{J} \mathrm{Mol}$ Med. 2016 Jun;37(6):1465-74.

105 Bang YJ, Giaccone G, Im SA, Oh DY, Bauer TM, Nordstrom JL, et al. First-in-human phase 1 study of margetuximab (MGAH22), an Fc-modified chimeric monoclonal antibody, in patients with HER2-positive advanced solid tumors. Ann Oncol Off J Eur Soc Med Oncol. 2017;28(4):855-61.
106 Rugo HS, Im SA, Wright GL, Escriva-de-Romani S, DeLaurentiis M, Cortes J, et al. SOPHIA primary analysis: A phase 3 (P3) study of margetuximab $(\mathrm{M})+$ chemotherapy $(\mathrm{C})$ versus trastuzumab $(\mathrm{T})+\mathrm{C}$ in patients $(\mathrm{pts})$ with HER2+ metastatic (met) breast cancer (MBC) after prior anti-HER2 therapies (Tx). J Clin Oncol. 2019 May;37:1000.

107 Trabolsi A, Arumov A, Schatz JH. T cell-activating bispecific antibodies in cancer therapy. J Immunol. 2019 Aug;203(3):585-92.

108 Kantarjian H, Stein A, Gökbuget N, Fielding AK, Schuh AC, Ribera JM, et al. Blinatumomab versus chemotherapy for advanced acute lymphoblastic leukemia. N Engl J Med. 2017 Mar;376(9):836-47.

109 Kiewe P, Hasmüller S, Kahlert S, Heinrigs M, Rack B, Marmé A, et al. Phase I trial of the trifunctional anti-HER2 $\mathrm{x}$ anti-CD3 antibody ertumaxomab in metastatic breast cancer. Clin Cancer Res. 2006 May;12(10): 3085-91.

110 Stagg J, Andre F, Loi S. Immunomodulation via chemotherapy and targeted therapy: A new paradigm in breast cancer therapy? Breast Care (Basel). 2012 Aug; 7(4): 267-72.

111 Zhang H, Lam L, Nagai Y, Zhu Z, Chen X, Ji $\mathrm{MQ}$, et al. A targeted immunotherapy approach for HER2/neu transformed tumors by coupling an engineered effector domain with interferon- $\gamma$. OncoImmunology. 2018 Feb;7(4):e1300739.

112 Han $\mathrm{H}$, Khong $\mathrm{H}$, Costa R, Loftus L, Goodridge D, Henry T, et al. Abstract P2-0915: A phase I study of interferon-gamma $(\gamma)$ plus weekly paclitaxel, trastuzumab and pertuzumab in patients with HER-2 positive breast cancer. Cancer Res. 2019:P2-09-15.

113 Mullins-Dansereau V, Petrazzo G, Geoffroy $\mathrm{K}$, Béland D, Bourgeois-Daigneault MC. Pre-surgical oncolytic virotherapy improves breast cancer outcomes. Oncoimmunology. 2019 Nov;8(11): 1655363

114 Ebrahimi S, Ghorbani E, Shafiee M, Ryzhikov M, Hassanian SM, Azadmanesh K. Therapeutic potency of oncolytic virotherapy in breast cancer targeting, current status and perspective. J Cell Biochem. 2019 Mar; 120(3):2801-9.
115 Choi AH, O'Leary MP, Fong Y, Chen NG. From benchtop to bedside: A review of oncolytic virotherapy. Biomedicines. 2016 Aug 2;4(3):18

116 Russell SJ, Peng KW, Bell JC. Oncolytic virotherapy. Nat Biotechnol. 2012 Jul 10;30(7): 658-70

117 FDA approves IMLYGICTM (Talimogene Laherparepvec) as first oncolytic viral therapy in the US [Internet]. [cited 2020 Aug 25]. Available from: https://www.prnewswire. $\mathrm{com} /$ news-releases/fda-approves-imlygictalimogene-laherparepvec-as-first-oncolytic-viral-therapy-in-the-us-300167270.html.

118 Sahin TT, Kasuya H, Nomura N, Shikano T, Yamamura K, Gewen T, et al. Impact of novel oncolytic virus HF10 on cellular components of the tumor microenviroment in patients with recurrent breast cancer. Cancer Gene Ther. 2012 Apr;19(4):229-37.

119 Nakao A, Kasuya H, Sahin TT, Nomura N Kanzaki A, Misawa M, et al. A phase I doseescalation clinical trial of intraoperative direct intratumoral injection of HF10 oncolytic virus in non-resectable patients with advanced pancreatic cancer. Cancer Gene Ther. 2011 Mar;18(3):167-75.

120 Comins C, Spicer J, Protheroe A, Roulstone $\mathrm{V}$, Twigger $\mathrm{K}$, White CM, et al. REO-10: A phase I study of intravenous reovirus and docetaxel in patients with advanced cancer. Clin Cancer Res. 2010 Nov; 16(22):5564-72.

121 O Bryan SM, Mathis JM. Oncolytic virotherapy for breast cancer treatment. Curr Gene Ther. 2018;18(4):192-205

122 Bourgeois-Daigneault MC, Roy DG, Aitken AS, El Sayes N, Martin NT, Varette O, et al. Neoadjuvant oncolytic virotherapy before surgery sensitizes triple-negative breast cancer to immune checkpoint therapy. Sci Transl Med. 2018 Jan;10(422):eaao1641.

123 Mullins-Dansereau V, Petrazzo G, Geoffroy $\mathrm{K}$, Béland D, Bourgeois-Daigneault MC. Pre-surgical oncolytic virotherapy improves breast cancer outcomes. Oncoimmunology. 2019 Aug;8(11):e1655363. 